\author{
Aleksandr Sinitsyn \\ https://doi.org/10.26485/AAL/2021/67/8
}

\title{
THE 'ARCHEOLOGY' OF HISTORIOGRAPHY AS A RHETORICAL AGON. ON THE JUXTAPOSITION OF HELLENIC WRITERS IN THE EPISTULA AD POMPEIUM BY DIONYSIUS OF HALICARNASSUS ${ }^{1}$
}

\begin{abstract}
Dionysius of Halicarnassus in his short theoretical treatise entitled "A Letter to Pompeius" (Epistula ad Pompeium) presents an exciting discussion on rhetoric mastership and scholarship written in an epistolary genre. The treatise begins with critical remarks Dionysius once addressed to Plato. The author admits to his addressee (Cn. Pompeius Geminus) that he is enchanted by Plato's dialogues. From the trio of Greek speech-makers who are recognized as the most brilliant in this respect - Isocrates, Plato, and Demosthenes (such was Dionysius's selection) - the Halicarnassean rhetorician deliberately dwells on Plato (Lysias, Isocrates, Demosthenes and other Greek orators are the subject of his other aesthetic works). Embarking on a wider discussion, Dionysius repeatedly points out that these studies are always aimed at establishing the truth. The longest chapter, 3 compares works of the first Greek historians and the mastery of their style. Dionysius points out the rivalry of the many masters of the genre, but the main characters of the chapter are Herodotus and Thucydides. The "father of history" (Dionysius' contemporary and paragon) surpasses the Athenian historian on all counts examined by the author. This article ex-

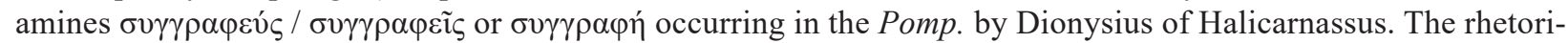
cian, when referring to Herodotus, Thucydides (ch. 3), Theopompus (ch. 6), Hellanicus, Charon (3.7) and the Greek

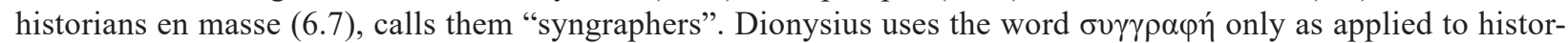
ical works of Theopompus of Chios $(6.2,3,6)$. The article also draws upon the Halicarnassian philologist's other works in which he mentions syngraphers-historians, who are set off against poets and orators. Dionysius regards

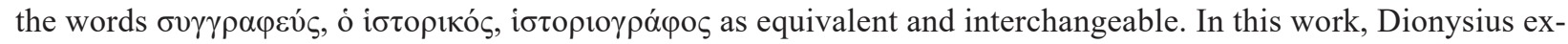
amines different styles of ancient writers. Here, by examining the works by the authors of the 5th and 4th centuries $\mathrm{BC}$ (written three to four centuries before his time) he seems to be performing a peculiar experiment of theoretical "archaeology". But the rhetoric and philological "archaeological" study conducted by Dionysius of Halicarnassus reveals not only his scholarly interest in the analysis of works of the writers of the past, but also his focus on the present - both in literary and cultural aspects. Plato is under the influence of Thucydides, but Thucydides is inferior to Herodotus, Herodotus produces works that surpass those of Charon and Hellanicus, while Theopompus is superior in style to Demosthenes himself and surpasses Isocrates - the "most brilliant" rhetoricians of the past. By presenting this gallery of names, Dionysius shows comparison as agon - of styles, genres, authors, their subject matters, intensive narrative, and he himself contends with the writers of the past. Seeing mastery of rhetoric as a peculiar agon stretching over centuries and across the agon of rhetoricians, philosophers and historiographers, Dionysius identifies the circle of best writers, and himself joins it. He claims that in the scholarly rhetoric "the truth is dearer still" and establishes the criteria to judge the classic writers. And the critic realizes that he will be judged according to the same (his own) criteria.
\end{abstract}

Key words: Dionysius of Halicarnassus, "A Letter to Pompeius", historiography, rhetoric, early Greek historians Hellanicus, Charon, Herodotus, Thucydides, Xenophon, Philistus, Theopompus, style, syngraphers, Plato, philosophy, ancient Greek orators Lysias, Demosthenes, literary criticism, polylogue, agon, influence

1 The research was carried out thanks to funding of Russian Foundation for Basic Research (project No. 19-0900022a "“Forefathers of history”: The oldest representatives of ancient historical science"). 


\title{
„ARCHEOLOGIA” HISTORIOGRAFII JAKO RETORYCZNA GRA. \\ O PORÓWNANIU GRECKICH AUTORÓW W „LIŚCIE DO POMPEIUSZA” \\ DINIZJOSA Z HALIKARNASU
}

\begin{abstract}
ABSTRAKT Dionizjos z Halikarnasu w teoretycznym traktacie zatytułowanym „List do Pompejusza” zawarł dyskusję na temat retorycznego mistrzostwa i nauki. Traktat rozpoczynają krytyczne uwagi Dionizjosa, adresowane do Platona. Autor przyznaje jednak, iż jest zachwycony dziełami Platona. Pośród trzech greckich mówców, uznawanych za najwybitniejszych - Izokratesa, Platona, Demostenesa - Dionizjos z Halikarnasu celowo studiuje Platona. Prowadzi szeroką dyskusję. Dionizjos wielokrotnie podkreśla, że wskazani autorzy mają na celu ustalenie prawdy. Najdłuższy rozdział oznaczony jako 3, dotyczy historyków greckich i stylu ich prac. Dionizjos zauważa rywalizacje mistrzów, ale głównymi bohaterami rozdziału stali się Herodot i Tukidydes. Dinozjos zauważa, że „ojciec historii” przewyższa ateńskiego historyka. Prezentowany artykuł dotyczy użycia słowa $\sigma v \gamma \gamma \gamma \rho \alpha \varphi \varepsilon v ́ \varsigma$. Słowa tego retor użył w odniesieniu do Herodota, Tukidydesa, Hellanikosa i innych historyków. Dionizjos wskazuje na styl autorów, tematykę ich prac.
\end{abstract}

Słowa kluczowe: Dionizjos z Halikarnasu, „List do Pompeiusza”, historiografia, retoryka, wcześni historycy greccy - Hellanikos, Charon, Herodot, Tukidydes, Ksenofont, Filistos, Teopompos, oratorzy, Lysias, Demostenes, krytyka literacka, agon

1. Introduction (About the optical judgement of an ancient source)

The philosopher M.K. Mamardashvili, beginning his first lecture on ancient philosophy, speaks about the history of philosophic thought as "a history of a single, though protracted, (here and elsewhere, italics are mine $-A$. $S$.) attempt people make at philosophizing". ${ }^{2}$ This view is interesting when we consider one domain of scholarship as a coherent, single research path. The train of philosophizing is understood as a synthesis of different ways of interrogation of those engaged in a "dialogue", a "polylogue", to be more precise, for it involves a wide range of interlocutors. This "exchange" is protracted, centuries old, and it will carry on as long as man is concerned with eternal issues, which, similar to the Magnesian stone, ${ }^{3}$ attract new generations of thinkers and scholars to a single field.

Experience of each "interlocutor" is unique and limitary, but the experiences of all participants make this polyphonic dispute a unified and, in point of fact, endless interaction. And here the agonal aspect is one of the most important components of the aggregate inter-contextual "polylogue". Contention among inquirers presupposes that everyone who has joined the common agon with his predecessors, contemporaries and associates of generations to come not only could try to comprehend and

2 Mamardashvili 1997: 7.

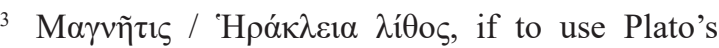
well-known metaphor (Ion. 533d-e); yet, the Athenian philosopher uses it on another occasion and in a different context. understand the world, but, first and foremost, could find their own positions. The same refers to the history of rhetoric, literature studies, history of historiography proper (about this later on), and various fields of humanities (and not only).

The above-adduced Mamardashvili's "formula" put me on to the optical judgement of a classical source I had to refer to when studying the theme of reception of the early Hellenic historians and philosophers in Antiquity. This sketch will speak of the literary rhetorical agon contained in the work of Dionysius of Halicarnassus, a historian of the second half of the 1 st century BC.

2. ... sed magis amica veritas: Ancient writers, Zoilus' criticism and the unveiling of truth

In his small theoretical, epistolary, treatise "A Letter to Pompeius" (Epistula ad Pompeium Geminum) Dionysius set forth an exciting discussion about the rhetoric prowess and scholarship of the Ancient Greeks. The work starts with critical remarks the author once made about Plato. The grammarian's opinion of the great philosopher did not accord with that of $\mathrm{Cn}$. Pompeius Geminus, to whom it was addressed (the latter, as follows from Dionysius' letter, was a great admirer of Plato. ${ }^{4}$

4 On Gn. Pompeius Geminus see, for example: Roberts 1900: 439-440; Goold 1961; Hidber 1996: 7-8; Fornaro 1997: 4; Aujac 2002a: 145, n. 1; Aujac 2002b: 29, 71, 72, 73 s., 161; de Jonge 2008: 26, 27 (with bibliography in nn. 138-141), 28, n. 149, 64, n. 85, 265, n. 57; Matijašić 2018: 67, 70, 72-73; de Jonge, 
Here is the beginning of the treatise:

"I have received with great pleasure the scholarly letter you sent me. Zeno, our common friend, has supplied you (so you write) with a copy of my treatises. In going through them and making them your own, on the whole you admire them, but are dissatisfied, you say, with one portion of their contents, namely, the criticism of Plato. Now you are right in the reverence you feel for that writer, but not right in your view of my position" (Dion. Hal. Pomp. 1.1). ${ }^{5}$

The author of the letter admits that he himself has been fascinated by Plato's skill of ver-

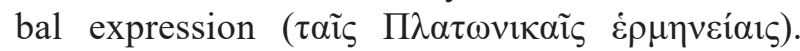
Dionysius states that he has always shown deference to all creators who gave their minds to the common good (Dion. Hal. Pomp. 1.2). Of the three Ancient Greek writers whom the grammarian of Halicarnassus calls "the most brilliant" ( $\lambda \alpha \mu \pi \rho o ́ \tau \alpha \tau o 1)$ - Isocrates, Plato and Demosthenes (such is Dionysius' selection, ibid. 1.5), - it is Plato's style he chooses to dwell upon. ${ }^{6}$ He devotes special literary and aesthetic works (some of which have never reached us) to Demosthenes, Isocrates, Lysias, Isaeus, Aeschines and other Greek orators. Dionysius discusses matters of writing style in his monumental works: "On combination of words" and "On Ancient Orators", in the extant fragments of the treatise "On imitation" and others.?

Hunter 2019: 8-9, 33 - here the authors of the Introduction to the collection on Dionysius of Halicarnassus note that his addressee, Cn. Pompeius Geminus, may have belonged to a circle of learned Greeks (he could have been a freedman of the Roman general and politician, Cn. Pompeius Magnus?), "who carried Roman citizenship, a Roman name and a Roman identity" (with reference to Thomas Hidber, who presents a discussion about this person: Hidber 1996: 7, n. 50).

5 Translated by W.R. Roberts in "The Three Literary Letters": Roberts 1901: 89.

6 In Pomp. 2.1 Dionysius says that this treatise will relate everything he wrote on Plato in another theoreti-

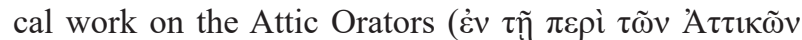

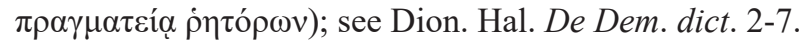

Selectively: Christ 1889: 474-479; Roberts 1910; Bonner 1939; Sacks 1983; Fox 1993; Hidber 1996; Reid 1996; Reid 1997; Weaire 2002; Weaire 2005; Walker 2005; de Jonge 2008; Osipova 2009; Strogetsky 2009; Osipova 2011a; Wiater 2011; Osipova 2013; Rushkin 2014: 185-189; Osipova 2015; Rushkin 2016; Matijašić 2018; Burrow 2019: 64-73; Meins 2019; Osipova 2019; Hunter 2019; Ivashkiv-Vashchuk 2020; Osipova 2021; Viidebaum 2021; Hanink 2021. On Dionysius of Halicarnassus as a literary critic, on the problems of his rhetorical works and his method there is a considerable
Dionysius begins his elucidation by saying that criticizing classical works does not mean disapproving of their authors. The student of rhetoric admits that he regards Plato "as a great man who had

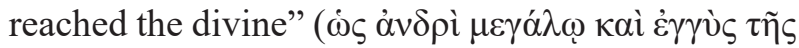

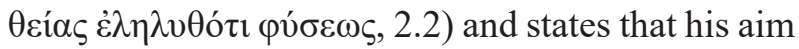
is not to attack Plato or, on the contrary, to create an encomium in his honour, not to condemn or justify the philosopher, but to "study different styles", by pointing out his strength and weaknesses.

Dionysius writes: "I admit to my sacrilege if I have at least one work containing any carping remarks at Plato the way Zoilus was apt to make" (Pomp. 1.4). The reference to Plato's contemporary, Zoilus of Amphipolis, (ca. 400-ca. 330 BC) is not fortuitous. This sophist, grammarian, historiographer and orator was well-known for his attacks at classics and contemporaries - Homer, Plato, Isocrates; he was branded under the cognomen of "Homeromastix" ('O $\mu \eta \rho \rho_{\alpha} \sigma \tau 1 \xi$ - "Scourge of Homer"), and for his severe criticism he was labelled "the rhetoric cur". 8 Here Dionysius compares him to Zoilus without condemning him; in the same chapter of his treatise the Halicarnassian classes the orator of Amphipolis among other $\tau \eta \lambda \iota \kappa o v ́ \tau o l ~ \alpha ้ v \delta \rho \varepsilon \varsigma^{9}$ who criticized Plato's teaching, finding fault in his works and ridiculing him. Yet it was Zoilus who was the talk of the town with philologists. ${ }^{10}$ The established ancient tradition

body of literature, as evidenced by the bibliographical list in the new collective monograph devoted to the scholar of Halicarnassus of the age of August: Hunter, de Jonge (eds.) 2019 (review of this edition: Poletti 2019; Nicholson 2020; Miano 2020; Friedman 2020); also see the part of the new monograph examining language, style and ethos in the ancient literary criticism: Jónsson 2021: 31-38 (review of the latest papers on the rhetorical works of Dionysius), 39-43, 132-134, 139-144 et al.

8 See Ael. Var. hist. 11.10: "Zoilus of Amphipolis, the one who wrote against Homer, Plato and other [authors] ... Zoilus was called the 'rhetorical cur' (Kv́wv

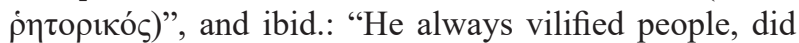
nothing but make enemies, and was amazingly quarrel-

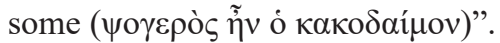

9 Dion. Hal. Pomp. 1.16: "Aristoteles, and next Cephisodorus, and Theopompus, and Zoilus, and Hippodamas, and Demetrius, and many others".

10 Novokhatko 2020: 113. On Zoilus and his method, see the comprehensive article by I.V. Shtal (Shtal 1975: 335-360) that features the apology of principles of literary criticism by this philologist and sophist. Drawing upon the evidence provided by Dionysius of Halicarnassus and scholia (from Porphyry), the author notes, "the orator Zoilus could and was to offer, as is 'usual' with orators, ... criticism of Homer, and this criticism, likewise 
(and then the further European tradition) portrays the ardent "rhetorical cur" as a paragon of radical and odious criticism: spiteful, mean-spirited, and cantankerous. He condemned Homer for depicting gods as wicked, heroes as ludicrous and their behaviour as illogical.

Yet, according to the proverbial "Aristoteles" maxim, amicus (mihi) Plato, sed magis amica veritas. And embarking on the exposition of his views on Plato's works, Dionysius of Halicarnassus keeps noting that any investigation (surely, a true one!) aims at laying bare the truth. ${ }^{11}$

that of Zoilus and others toward Plato, may have pursued a particular aim - 'to establish the truth"' (Shtal 1975: 344). The scholar comes to the conclusion that Zoilus through his activities was "laying the foundations for the future: the Alexandrian school of philology" (Shtal 1975: 356). Schooled in the art of rhetoric by Polycrates, the Athenian orator and sophist $\left(5^{\text {th }}-4^{\text {th }}\right.$ centuries BC), Zoilus marked a certain stage along the path of the Homer hermeneutics (as well as that of Plato, and not only) from Athens to Alexandria (see the above-mentioned article by A. Novokhatko). I.V. Shtal examines the evidence provided by ancient and Byzantine sources about Zoilus, including those by Dionysius of Halicarnassus (Shtal 1975: 335-344), adduces examples of criticism and interpretations of Homer by the orator from Amphipolis, who painstakingly searched for all sorts of faults in the "Iliad" and the "Odyssey" (Shtal 1975: 347-356). On Zoilus also see: Apfel 1938: 250-252; Radermacher 1951: 198-200; Buffière 1956: 22-25; Fraser 1970; Gärtner 1964b; Gärtner 1978 (both articles in Kleiner Pauly and Realencyclopädie together with the most significant literature of the $19^{\text {th }}-20^{\text {th }}$ centuries); Branham 1996: 84-85 (here Zoilus is shown as a "minor figure" among the early cynics: "prototypical or minor figures such as Antisthenes or Zoilus", "a Cynic as marginal as Zoilus"); Lockwood, Browning 1996 (=2012); Matthaios 2002; Szlezák 2012: 18-19; Williams 2013 (a corpus of fragments and evidences); Goulet-Cazé 2018: 421-436 (a most detailed of the latest reviews and studies on Zoilus and the subject matter of his works); Pavlova 2019 (on the remark made by Aristoteles in the last-but-one part of the "Poetics" [1461b], that may have been aimed against criticism of Zoilus, based on the wrong interpretation of the sources: analysis of three fragments ascribed to Zoilus in which the orator of Amphipolis highlights the discrepant details and tries to mock not Homer's text but his own - injected - ideas of him); Novokhatko 2020: 112-120 (with selected bibliography: p. 112, n. 92). I will also indicate a new resource, 'Brill', which contains articles from "Lexicon of Greek Grammarians of Antiquity" (Regali 2020).

11 Note by Gabriella Ottone: "È noto che la ricerca della verità era l'essenza stessa della speculazione platonica, e di quella filosofica in generale...; pur a fronte di questo, nell' Epistola a Pompeo Dionigi impostava l'apologia della propria critica antiplatonica sull'insinuazione
"But when he wishes to determine what is most excellent in some walk of life and what is the best among a number of deeds of the same class, he ought to apply the most rigorous investigation and to take account of every quality whether good or bad. For this is the surest way of discovering truth, than which there is no more precious boon ( $\dot{\eta} \gamma \alpha \grave{\alpha} \rho \dot{\alpha} \lambda \hat{\eta} \theta \varepsilon 1 \alpha$

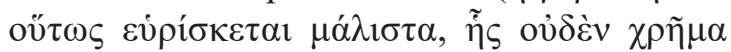
$\tau \iota \iota 1 \dot{\tau \varepsilon \rho o v) " ~(D i o n . ~ H a l . ~ P o m p . ~ 1.3) . ~}{ }^{12}$

Only by $\dot{\varepsilon} \xi \dot{\varepsilon} \tau \alpha \sigma \iota \varsigma$ can one elucidate $\dot{\alpha} \lambda \dot{\eta} \theta \varepsilon 1 \alpha,{ }^{13}$ and with this noble aim in view, according to the scholar of Halicarnassus, he is determined to "juxtapose certain good [authors] with other good [au-

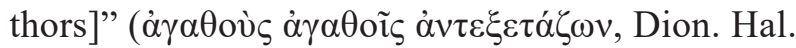
Pomp. 1.17). Comparisons that Dionysius uses here are demonstrations of rivalry among the best

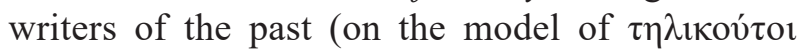
öv $\delta \rho \varepsilon \varsigma$, as he points out).

3. The rhetorician's criticism of ancient authors from Plato to Theopompus (A review of and commentaries on Dion. Hal. Pomp.)

Let us examine the main points of "The Letter to Pompeius" by Dionysius of Halicarnassus.

i. The treatise begins with judgements of Plato. ${ }^{14}$ The first chapter speaks about the principles of the Plato criticism. The author chooses "Phaedrus", in which Socrates, the Athenian philosopher (= Plato), argues with the orator Lysias (Dion. Hal. Pomp. 1.10). ${ }^{15}$ This work, after three

che il filosofo avesse falsato la verità" (Ottone 2017: 104, here with reference to Dion. Hal. Pomp. 1.14).

12 Roberts 1901: 91.

13 Cf. Dion. Hal. Pomp. 1.3; 6; onwards in the same chapter: "Many renounced his (Plato's $-A$. $S$.) teaching and found fault in his works..., ridiculed him not out of envy or spite, but out of the desire to establish the truth ( sion of the nature of historical truth and practical applicability of historical knowledge based on the literary (rhetorical) and historiographic material of Dionysius of Halicarnassus, see F. Meins' monograph (Meins 2019). I'll refer to the reviews of this study I know of: Matijašić 2020 (with notes, interesting analysis and friendly comments); Miano 2020 and Gershon 2021 (a highly critical review).

14 On composition of the work, see: Aujac 2002b: 71-75 (here about the first, "Platonian', chapters": pp. 7273); cf. Fornaro 1997.

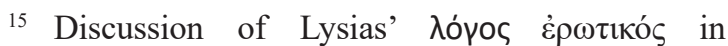
"Phaedrus" as a text written by a logographer (Plato. Phd. $257 \mathrm{c}$ ), that is, a composer of speeches, whose success 
speeches (the first - Phaedrus reading Lysias's speech + two speeches by Socrates),${ }^{16}$ criticizes the contemporary rhetoric mastery and presents a view on "the true $\tau \dot{\varepsilon} \chi v \eta "$ (Plato. Phd. 271c-d). In "Phaedrus" Plato deliberates on the rules of the art of speech and strives to show that a true orator is a philosopher. ${ }^{17}$ But Dionysius condemns Plato for his "poetic embellishments", which, in his opinion, are out of place in a prosaic work. ${ }^{18}$

Dionysius points out that Plato mocked many of his fellows, ${ }^{19}$ notable thinkers: Parmenides, Hippias, Protagoras, Prodicus, Gorgias, Polus, Theodorus, Thrasymachus ${ }^{20}$ and other predeces-

depends on the impression these speeches produce on the public (ibid. 258a-b), see a new paper by Jenny Bryan "The Role of Lysias' Speech in Plato's Phaedrus": Bryan 2021: 1-21. On Plato's criticism in "Phaedrus", see also: Adkins 1996; Buccioni 2007; Werner 2010; Glukhov 2014: 269285; Szlezák 2015 (on major notions of Plato's criticism in "Phaedrus"); Galanin 2020: 96-100 (on rhetorical dimensions of the dialogues "Lysis" and "Phaedrus"); Hartmann 2020 (here about the specifics of philosophical rhetoric in the dialogue "Phaedrus", "Gorgias", and "Timaeus"). Specifically on the analysis of style of Plato's "Phaedrus" in the works by Dionysius of Halicarnassus: Hunter 2012: 151-184. See the article by Laura Viidebaum " Dionysius and Lysias' Charm": Viidebaum 2019: 106-124, also: Yunis 2019: 90, 91 ff.; Schirren 2019: 186-187, 189-192 (on Lysias-ethographer), and Viidebaum 2021: 38-55.

16 See in Harvey Yunis: "For instance, in regard to Socrates' first speech on eros in the Phaedrus, Dionysius famously mistakes Plato's ironic, humorous imitation of grandiose style for sincere but bombastic effect (Dem. 7.3-7)" (Yunis 2019: 91).

17 On rhetoric and philosophy in Plato's "Phaedrus" see, for example: Werner 2010, 21-46 (with the support of vast literature); here, in particular: "Plato's account of the true $\tau \varepsilon \dot{\chi} \chi \eta$ seems to place rhetoric quite close to philosophy itself, and in particular to philosophical dialectic" (p. 21); "This is because the true orator does not practise speech-making in any traditional sense; the true orator is a philosopher. In other words, the ideal rhetoric merges with philosophy: philosophical inquiry is the necessary precondition for the $\tau \dot{\varepsilon} \chi \nu \eta$, and philosophical discourse is the nearest approximation of that $\tau \dot{\varepsilon} \chi v \eta "$ " $p$. 45). See also a new interesting work by M. Erler "Platon und seine Rhetorik": Erler 2019: 315-338.

18 Cf. Sobolevsky 1960: 161-162, and here also a remark by a Russian philologist: "In this case Dionysius is wrong in his criticism of Plato: In 'Phaedrus' Socrates deliberately speaks in high style, so this poetic colouring is highly appropriate" (Sobolevsky 1960: 162, n. 16).

19 On laughter and irony in Plato, I will cite recent papers: Prokopenko 2016; Shcherbakov 2021 (both with a certain bibliography for the topic).

20 These sophists and orators, Parmenides, Hippias, Protagoras and Gorgias, are the main characters sors and contemporaries (Dion. Hal. Pomp. 1.12; cf. ibid. 1.16 and 17). The critic of Halicarnassus reminds his addressee (as well as the "general public") this historical and rhetorical treatise aims at that Plato proposed to expel from his ideal polity even Homer himself. ${ }^{21}$

ii. In the second chapter the author juxtaposes Plato with the outstanding orators. According to Dionysius, the Athenian philosopher modelled on Gorgias borrowing his "poetic devices". 22 Plato is given to verbosity, he seeks to use fine language, he is too obsessed with lofty and copious style, but he is not always successful there. The rhetorician from Halicarnassus clarifies his attitude:

"Let no one suppose that I say this in general condemnation of the ornate and uncommon style which Plato adopts I should be sorry to be so perverse as to conceive this opinion with respect to so great a man. On the contrary, I am well aware that often and on many subjects he has produced writings which are great and admirable and of the utmost power. What I desire to show is that he is apt to commit errors of this description in his more ornate passages, and that he sinks below his own level when he pursues what is grand and exceptional in expression, and is far superior when he employs the language which is plain and exact and seems to be natural but is really elaborated with unoffending and simple artifice" (Dion. Hal. Pomp. 2.7). ${ }^{23}$

Before and after Dionysius, the European tradition treats Plato as a classic of the Attic parlance and eloquence. ${ }^{24}$ But, according to a stern and unprejudiced critic from Halicarnassus, Gorgias' rhetoric art was the true paragon for Plato. Yet, the word "unprejudiced", in spite of Dionysius's assurance and declarations of his allegiance to $\alpha \lambda \eta \dot{\eta} \theta \varepsilon \iota \alpha$,

in the Plato's works after whom these works received their titles. The four others are characters in various Plato's dialogues.

21 Criticism of Homer and Hesiod, as well as of tragedy and comedy dramatists takes a large part on Books 2 and 3 of Plato's "Republic". While Dionysius mentions only a radical occasion - Plato's denial of the Poet of Poets. Cf. Dion. Hal. Pomp. 1.13-14.

22 Dion. Hal. Pomp. 2.6; 2.8; 2.13: "His (Plato's A. S.) fault is that, in imitation of the school of Gorgias, he has introduced the pomp of poetical artifice into philosophical discourses, so that some of his productions are of the dithyrambic order". See Fornaro 1997: $8 \mathrm{seg}$. ("Contro Platone"), 14-16.

23 Roberts 1901: 99, 101.

24 See, for example: Markov 2014; Semikolennykh

2015. 
can be put in inverted commas here since, as will be shown at the end of the article, the critic could have his own personal interests in drawing this rhetorical comparison. Dionysius notes that Plato was under the influence of a well-known sophist orator, Gorgias, and his younger contemporary, though no less famous, historian, Thucydides ${ }^{25}$ ("under the influence of his devices", Pomp. 2.8); as to $\tau$ ò inferior to Demosthenes". ${ }^{26}$

iii. The longest part of the treatise, the third one, where the author compares works by earlier Hellenic historians. ${ }^{27}$ Here Dionysius introduces the names of several masters of historiography who worked in the classic era, ${ }^{28}$ but the major heroes of the section are Herodotus and Thucydides. ${ }^{29}$

25 On various parallels and overlappings in the works of Thucydides and Plato there is vast literature (largely, of historical and political orientation); for example: Grene 1967; Barton 2006; Mara 2008; Samons 2010; Svetlov 2016; Mara 2017 (with bibliography for the topic).

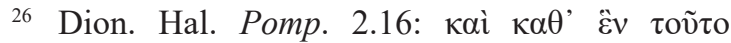

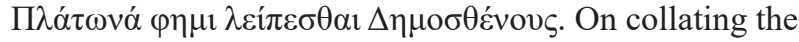
styles of Plato and Demosthenes in the treatise by Dionysius of Halicarnassus "On Demosthenes", see Reid 1997. The researcher notes that presenting Demosthenes' speeches as a paragon of literary style, Dionysius chooses for comparison the "Apology of Socrates" as a vision of Plato's style. Of recent works, see: Hunter 2012: 109150 (Chapter 3 "Plato, Lysias and Isocrates"); Viidebaum 2019; Yunis 2019 (all publications with bibliographies); Viidebaum 2021, passim (esp. pp. 6-10, 176-213 [ch. 7 "Dionysius of Halicarnassus on Lysias, Rhetoric and Style"], 214-244 [ch. 8 "Isocrates and Philosophy in Dionysius of Halicarnassus' Rhetorical Writings"]). The orator from Halicarnassus devotes to Demosthenes "an exalted hymn" (Sobolevsky 1960: 159); it conveys the rapture that he feels on hearing the speeches by the Athenian orator (Dion. Hal. De Dem. dict. 22).

27 S.L. Jónsson defines the criteria set by Dionysius of Halicarnassus in "The Letters to Pompeius" to assess the style and content of works by ancient authors, where the latter compares the language of Herodotus and Thucydides (Jónsson 2021).

28 Specifically on early Greek historians in Dionysius, see: Jacoby 1949: 86-87, 178-185; Toye 1995; Matijašić 2018. Also Fornara 1983: 17-20; Gabba 1991; Joyce 1999; Schultze 2000: 19 ff., 25-26 (+ here discussion in n. 53); Laird 2009; Osipova 2009; Osipova 2011a; Osipova 2013; Scanlon 2015: 146 ff.; de Jonge, Osipova 2018; Hunter 2019: 3-4; Schultze 2019: 177-178; Osipova 2019; Ivashkiv-Vashchuk 2020: 68-70; Osipova 2021. On Herodotus and Thucydides in the ancient rhetorical tradition, see the Ph.D. thesis: Kennedy 2018a.

29 A critical analysis of the style of the Athenian historian is contained in the treatise "On Thucydides"
At almost all points examined by the orator of Halicarnassus, his countryman Herodotus excels his younger colleague. ${ }^{30}$ The most important comparison point is $\dot{\pi} \pi 0 \theta \varepsilon \dot{\sigma \varepsilon} \measuredangle \varsigma$ chosen in their historical works (Dion. Hal. Pomp. 3.3, 8-10; cf. Id. Thuc. 6, 10, 12), as Dionysius holds, Thucydides was unwise to choose the Peloponnesian war as the topic for his work ${ }^{31}$ because for the Greeks it was not a mark of pride. ${ }^{32}$ But the war that Herodotus wrote about should be regarded as glorious and victorious for the Athenians and the Spartans. So Herodotus' choice is wiser than that of Thucydides (Pomp. 3.6). And the critic highlights the rivalry between the "father of history" and his contemporaries. ${ }^{33}$

and "The Second Letter to Ammaeus". See Grube 1950; Sobolevsky 1960: 162-164; Pritchett 1975; Fornaro 1997; Aujac 2002a. Selected literature: Weaire 2002; Weaire 2005; Lévy 2010; Rushkin 2014; Irwin 2015; Rushkin 2016; Hunter 2019. See in the well-known work by S. Bonner on Dionysius' critical method: Bonner 1939: 59-97.

30 "He (that is, Dionysius - A. S.) has set Herodotus and Thucydides at the top of his personal podium of historians, with a clear preference for the Halicarnassian" (Matijašić 2018: 81).

31 Cf. "Merely local history made little appeal to Dionysius. In Ep. ad Pomp. 3, he prefers the sort of subject treated by Herodotus, the story of a struggle that was epic in its character and afforded the fullest scope for the historian's power, over that of Thucydides" (Pritchett 1975: 56-57, n. 35 ad loc. Dion. Hal. Thuc. 5.5).

32 See: "Thucydides, on the other hand, writes of a single war, and that neither glorious nor fortunate; one which, best of all, should not have happened, or (failing that) should have been ignored by posterity and consigned to silence and oblivion" (Dion. Hal. Pomp. 2.16; Roberts 1901: 99, 101). Here Dionysius of Halicarnassus shows his attitude not as a historian but as a philologist. $\mathrm{He}$ is concerned about the chosen topic, a proper description (arrangement of the material and combination of words), and about the past per se, it does not matter what the past events were like: horrible, shameful, fatal, self-defeating, sinister, disgraceful, disastrous, etc. See: Matijašić 2018: 73-78 (Herodotus vs. Thucydides), 97 ff., 123-128; Wiater 2019, 80 ff.

33 The two significant figures referred to by Dionysius are usually related to Herodotus' predecessors, "forefathers of history" (who are commonly, though mistakenly, called "logographers"). Charon of Lampsacus was the elder contemporary (he lived and worked in the first half of the 5th century); while Hellanicus of Mytilene on Lesbos was Herodotus' contemporary (and probably his coeval, he was also born in the 480s BC), and he outlived the "father of history" by a couple of decades (died at the end of the 400s BC). On the very prolific and famous inhabitant of Mytilene, see: Niese 1888: 81-91; Perrin 1901; Jacoby 1912 (= Jacoby 1956: 
"Very different was the course taken by Herodotus. Although his predecessors, Hellanicus and Charon, had previously issued [his-

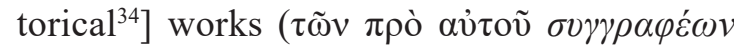

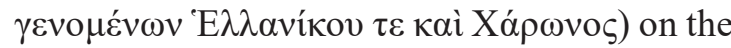
same subject, he was not deterred, but trusted his own ability to produce something better. And this in fact he has done" (Pomp. 3.7). ${ }^{35}$

Herodotus includes in his epic historiography various digressions, as did the "first writer of history", Homer, and here the "father of history" is referred to as a imitator of Homer. ${ }^{36}$ According to

262-287); Pearson 1939; Jacoby 1949; Gärtner 1964a: 1004, 1005; Fornara 1968; Mosshammer 1973: 5-13, esp. p. 7-9 (about the akme of Hellanicus [456/5], mentioned by Apollodorus: FGrHist 244 F 7); Ambaglio 1980; Fowler 1996; Joyce 1999: 1-17; Möller 2007: 241-262; Sánchez Jiménez 2007; Lenfant 2009: 9-24; Strogetsky 2010: 105-107, 121-122; Ottone 2010a; Alganza Roldán 2012; Irwin 2013; Alganza Roldán 2015; Baurain-Rebillard 2016; Condilo 2017; Matijašić 2018: 182-183, 218 ff.; Polychronis 2018 (the most detailed today is the study of the "archives" of Hellanicus, with translations of the extant fragments and comments on them); Tufano 2019: 40-49, 59-67, 75-129, 444-452; Surikov 2021.

34 Here, as in all other cases in "The Letter to Pom-

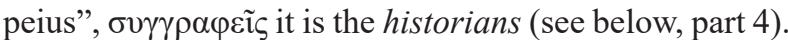

35 Roberts 1901: 107.

36 Dion. Hal. Pomp. 3.11: "Herodotus sought to diversify ( $\pi$ oเкí $\lambda \eta v)$ his work, following Homer in that"; here, it says literally that the historian was an im-

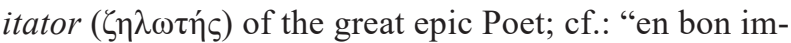
itateur d'Homère" (Aujac 2002b: 90). See "Readers of Herodotus both ancient and modems have found the imprint of Homeric epic on all levels of his text, from the occasional use of special poetic words, to literary tropes such as set speeches and dialogues, to overall range and purpose. Herodotus occasionally refers to epic characters and deeds; moreover, story patterns familiar from myths emerge from time to time in the Histories" (Boedeker 2002: 97). And also: "Dionysius of Halicarnassus extols Herodotus as the most 'Homerian' writer and argues that his prosaic style proved very close to poetry" (Borukhovich 1982: 242); "To Homer he undoubtedly owes much, in cast of thought as well in language" (Denniston, Pearson 1970: 509). Ancient authors compared the historical prose of Herodotus with the poetry of Homer; for example: Strabo. 1.3.18; Luc. Hist. conscr. 14; Quint. Inst. Orat. 10.1.73-74; Ps.-Long. De

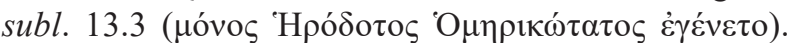
The influence of the Homerian epos on Herodotus' work has been frequently emphasized; see the collective monograph: Baragwanath, Bakker (eds.) 2012. On

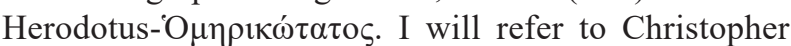
Pelling's article (Pelling 2006) and the article by John Marincola (Marincola 2018, for the discussion, see in
Dionysius, all the digressions Herodotus resorts to are skilfully enwoven in the text of his work, thereby creating an impression that the military and historical work by Thucydides, in spite of its focus on one theme, is fragmented, while that of Herodotus seems integral. It is telling that the author of the treatise speaks about Herodotus" "History" as a complete and harmonic work. He believes that the historian succeeded in completing his work on the great war waged by Hellenes and the barbarians: the finale speaks about Hellenic victories, the banishment of the Persians and the liberation of Hellas: ${ }^{37}$

"...he (Herodotus $-A$. S.) does not break the continuity of the narrative. The general result is that, whereas Thucydides takes a single subject and divides one whole into many members, Herodotus has chosen a number of subjects, which are in no way alike, and has

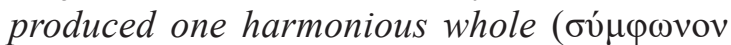

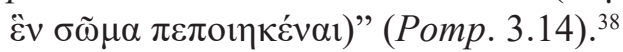

the review of the collection devoted to Herodotus: Sinitsyn, Surilov 2019: 185-187; Sinitsyn, Surikov 2020a, 359-360); Selected literature in Sinitsyn 2009: 58, n. 103; Sinitsyn 2019: 84, n. 2; and new works: Pelling 2019; Pelling 2020; Fragoulaki 2020a, XXI-XXII, XXIV-XV, XXXII, XXXVIII; Fragoulaki 2020b, 37-38 (here in note 2 provides selected bibliography), 39, 42, $52 \mathrm{f} ., 67 \mathrm{ff}$. et al.

37 On the discussion of the issue of completion of Herodotus' Histories, see in my articles: Sinitsyn 2013; Sinitsyn 2017a; Sinitsyn 2017b; Sinitsyn 2019 (with bibliography in every cited work). On the discussion about the issue of recent publications: Herington 1991; Boedeker 1988; Lateiner 1989: 45, 46-50, 119, 243, 244, 257; Moles 1996; Gasparov 1997; Pelling 1997: 59-63, Dewald 1997; Desmond 2004; Welser 2009: 367-372; Rosen 2009; Grethlein 2009; Hamel 2012: 286-290; Irwin 2013; Raaflaub 2016: 596-598; Irwin 2018; Sheehan 2018: 243-249 (notes to the "Guide to Herodotus" by Sean Sheehan, see: Sinitsyn, Surikov 2020b = Sinitsyn, Surikov 2021).

38 Roberts 1901: 113. Talking about the theme of Herodotus' work, formulated by him in the famous prooemium (Hdt. 1: "What Herodotus the Halicarnassian has learnt by inquiry is here set forth: in order that so the memory of the past may not be blotted out from among men by time, and that great and marvellous deeds done by Greeks and foreigners and especially the reason why they warred against each other may not lack renown"; Godley 1975, 3), the critic of Halicarnassus notes (Pomp. 3.4): "This introduction is the beginning

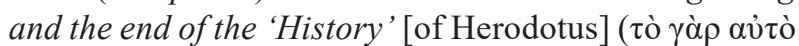

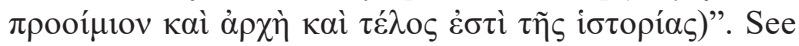
Pritchett 1975; Strogetsky 2010: 121-122, 130-133. 
Dionysius is highly critical even of Thucydides' chronological method, which was a source of particular pride for the Athenian historian: ${ }^{39}$

"Thucydides keeps close to the chronological order, Herodotus to the natural grouping of events. Thucydides is found to be obscure and hard to follow. As naturally many events occur in different places in the course of the same summer or winter, he leaves half-finished his account of one set of affairs and takes other events in hand. Naturally we are puzzled, and follow the narrative impatiently, as our attention is distracted" (Pomp. 3.12-13). ${ }^{40}$

The historian of Halicarnassus in his search of truth rejects Thucydides' principle of historiography because events are divided into periods, time cycles, which makes him divert from one account to another, and yet another... only to return to the

39 Thucydides' work is structured on an "annalistical" pattern: the whole war is divided into periods years, and every year is halved - into the summer season and the winter season (war campaigns). He is deemed to be the first to establish this principle to determine the accounts of historical events (selectively, on the structure of "The Histories" and Thucydides' system of periodization: Classen, Steup 1912: $54 \mathrm{ff}$., $257 \mathrm{ff}$., ad loc. 5.20.2 sq.; Sobolevsky 1955: 78-87; Gomme 1956a: 1, ad loc. Thuc. $2.1+$ Appendix, p. 699-715, 716-721; Gomme 1956b: 685 ff., ad loc. 5.20.2-3; Meritt 1962; Pritchett 1964; Luschnat 1970; Rawlings 1981; Hunter 1977; Hornblower 1991: 38; Hornblower 1996: 490-493, ad loc. 5.20; Sonnabend 2004: 69 ff.; Dewald 2005; Irwin 2015). Of his special way the historian says (2.1): "The events of the war have been recorded in the order of their occurrence, summer by summer and winter by win-

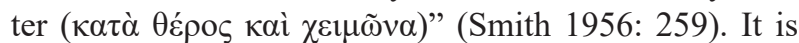
indicative that Thucydides frequently (Thuc. 2.1; 5.20.2 sq.; 5.26.1, 3) reiterates the importance of the principle

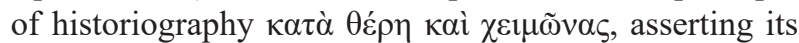
rightness. Thucydides deems his yearly-season method to be a novelty (cf. Hornblower 1991: 235: "Such an arrangement was a novelty (surely, of Thucydides $-A$. S.)..."; Rengakos 2006: 284: "a Thucydidean innovation"), with which he is determined to ensure the exact dating of the war events, that is why he is so particular in elucidating the importance of the chronological system he sets forth. And such method of marking is essential for the stern Athenian historian.

40 Roberts 1901: 111, 113. On Dionysius' criticism of Thucydides' chronological method, see, for example: Wille 1968; Losev 1977: 108-110; Gabba 1991: 65 ff; Toye 1995; Osipova 2010; Osipova 2011a; Wiater 2011: 132-154 (here $\S 3.2 .1$ - on the juxtaposition by the philologist of Halicarnassus of the principles established by the first historians); Osipova 2013; Irwin 2015, 125, 127 f. (+ n. 11), 170-171. interrupted story, and then he breaks the account again to switch on to something else. ${ }^{41}$ All this, according to Dionysius, creates an impression of fragmentation, which makes it difficult for readers to understand. ${ }^{42}$ Yet, these objections made by the philologist of Halicarnassus to Thucydides do not seem fairly convincing.

In content, as Dionysius holds, Thucydides is inferior to the "father of history", but "in style, he is sometimes worse, sometimes better, sometimes equal to him" (ibid. 16). In the finale of chapter 3 , the orator uses the "formula" to compare the two classic historians, the one modern scholars and students of the early historiography have frequently referred to when studying Dionysius:

"It may be said in general that the poetical compositions (as I should not shrink from

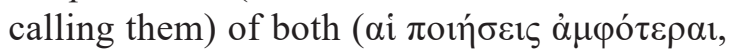
i.e. Herodotus and Thucydides $-A$. S.) are beautiful $(\kappa \alpha \lambda \alpha i)$. The chief point of difference is that the beauty of Herodotus is

41 On the "technique of interweaving", which Thucydides uses in "The History of the Peloponnesian war", see, for example: Hornblower 1996: 256-257, 403; Dewald 2005; Rengakos 2006; Sinitsyn 2009: 56-58.

${ }^{42} \mathrm{Cf}$. the same in his other work: "But Thucydides chose to follow a new path and one that had not been trodden by others, and divided his work by the events of summers and winters. The effect of this was different from what he had expected. The chronological division has not become clearer, but it is more difficult to follow..." (Dion. Hal. Thuc. 9; trans. by Pritchett 1975: 5) Then with examples of "discontinuity of narration" from Book 3 of "The History of the Peloponnesian war" and the harsh condemnation as to the chronological novelty of Thucydides: "The whole book has thus been chopped up into small bits and has lost the continuity of the narrative. We lose our way, as is natural, and it is hard for us to follow the narrative, our mind being confused by the tearing asunder of the events, and being unable easily and exactly to remember the half-finished reports it has heard. The events narrated in an historical treatise must follow without interruption, especially when the events are many in number and hard to follow. It is plain, then, that the Thucydidean canon is not suited to history. For none of the later writers divided his history by summers and winters, but all of them followed the beaten paths that lead to clearness" (Ibid.; Pritchett 1975: 6) After that Dionysius adduces more examples of "digressions" made by the Athenian historian from the general theme and a faulty arrangement of the material (Ibid. 13-17; the discussion of these chapters of the treatise "On Thucydides" and remarks on the criticism of the Athenian historian by the philologist of Halicarnassus, see Oakley 2019: 128-130). 
radiant (i $\lambda \alpha \rho$ ós), that of Thucydides aweinspiring (

Collating the prosaic texts with the poetic

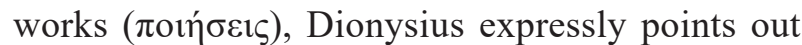
the significance of the aesthetic aspect of historical works. In his work on the history of Rome, he put an emphasis on the importance of "good themes"

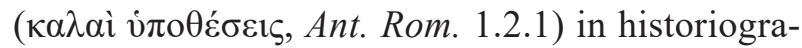
phy, time and again stressing the need for "good

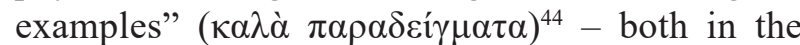
"Roman Antiquities" and rhetorical treatises.

iv. The following two parts are relatively short. In chapter 4 Herodotus is compared to Xenophon, whom Dionysius features as an imitator ( $\zeta \eta \lambda \omega \tau \eta \dot{s})$ of the "father of history" both "in content and style" (Dion. Hal. Pomp. 4.1). The Athenian historian is

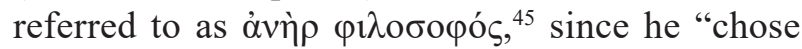
noble and grand themes for his historical works

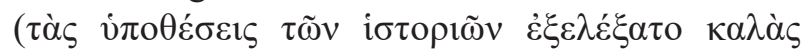

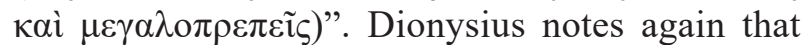
he chooses fortunate topics in his modelling upon Herodotus (4.2), though Xenophon's style is inferior to that of Herodotus. "Herodotus also boasted grandeur, beauty and splendour and what can be

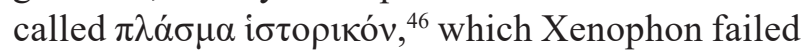
to borrow [from him]..." (4.3)

43 Roberts 1901: 117. As to the rhetoric and poetics in theoretical works in Aristotle and Theophrastus to Philodemus (and partly, Dionysius), see Beer 2019: 378-379. On the poetic influence and reminiscences in the works of Dionysius of Halicarnassus, see the work de Jonge 2019 (mainly, *on the poetry of Horace). Casper de Jonge recognizes close similarity between a particular part of Horatio's Ars poetica and the discussion of the tasks set by the historian in Dionysius" "The Letter to Pompeius" (Jonge 2019: 245).

44 See ch. 3 in the monograph by Friedrich Meins (Meins 2019), which discusses the value of beauty

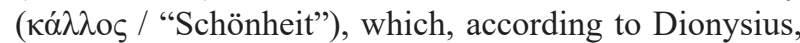
a true historical work must reveal.

45 On the historian Xenophon as princeps philosophorum, see: Matijašić 2018: 58-65.

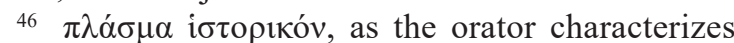
Herodotus' style, W.R. Roberts renders into English as an exquisite phrase "historical vein": "and what is specifically called the "historical vein" (Roberts 1901: 119). A similar variant is found in Russian translation by O.V. Smyka: “историческая жилка” (Smyka 1978: 231). Here Dionysius speaks about Herodotus' mastery, his special manner of historical writing. One of the meanings of the word $\pi \lambda \alpha$ $\sigma \mu \alpha$ in the classical LSJ dictionary: "formed style in writing or speaking", and the authors adduced the phrase of our concern from chapter 4 of Dionysius" "The Letter to Pompeius" as an example from the ancient sources (LSJ: 1412, s.v. $\pi \lambda \alpha \dot{\sigma} \sigma \mu \alpha$, III.1); cf. Roberts 1910: 317, s.v. $\pi \lambda \alpha \dot{\sigma} \mu \alpha$ (also with v. Chapter 5 compares Philistus of Syracuse with Thucydides. According to Dionysius, Philistus had mastered his style under the influence of his famous Athenian predecessor. ${ }^{47}$ One of the pithy reproaches Dionysius made to Thucydides and Philistus is that these historians chose local, petty topic, that they are interested only in local history, and narrowed down to a particular event vं ó $\theta \varepsilon \sigma 1 \varsigma:$ with Thucydides it is the Peloponnesian war, with Philistus, it is the history of Sicily. Both do not produce momentous works of world history, which would describe international affairs and encompass a long period of time, as was the case with other historiographers.

Dionysius' judgement is harsh: Philistus' arrangement of material leaves much to be desired, and it is even more difficult to follow the sequence of events than it is in Thucydides' text. As the orator shows, in many points the historian from Syracuse is inferior to the Athenian scholar (Dion. Hal. Pomp. 5.2-3).48 "Likewise Thucydides, he (Philistus $-A$. S.) does not divert from the topic

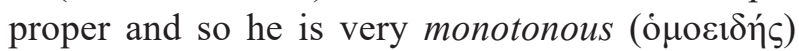
(5.2). And to demonstrate the monotony and scantiness of the language used by the Sicilian historiographer (who often uses "several identically structured periods" in a row, 5.4), Dionysius adduces a passage from his work "On Sicily" that lists ethnonyms and repeats sentences of similar structure (5.5). ${ }^{49}$ Indeed, the cited fragment looks mo-

an example from Pomp. 4). See the English version by Stephen Usher in "Loeb": "and what is called by the special name of "the historical cast of style" (Usher 1985: 389); cf. the old Latin version: "suavem conformationem historicam, quemadmodum Herodotus, non habet (Xenophon - A. S.)" (Reiske 1777: 779); cf. also the French version by Germaine Aujac in the series "Budé": "et ce qu'on appelle proprement le mode d'écriture historique" (Aujac 2002b: 94) and in the same edition, clarification of this word in the Dionysus lexicon: "forme d'écriture, style (mot du vocabulaire stoīcien); fiction" (Aujac 2002b: 261, s.v. $\pi \lambda \alpha \dot{\sigma} \mu \alpha)$.

47 On the historian Philistus as an imitator of Thucydides, see, for example: Fromentin 2010 ("Philistos de Syracuse, imitateur de Thucydide"); Matijašić 2018: 7882, 146 f., 169-172 ("imitator of Thucydides").

48 Cf. "At Ad Pomp. 5 Thucydides appears as a kind of benchmark for taxis that is difficult to follow, Philistus being 'worse than Thucydides' in this respect" (Irwin 2015: 128, n. 11).

49 FGrHist 556 F 5. See Schindel 2004: 163-169; Tober 2017: 463-464. On discussion of the subject of Syracuse's casus belli and the neighbouring town of Camarina, and on their allies, see Di Stefano 1988-1989; 
notonous, trite, oversimplified, dry and boring ${ }^{50}$

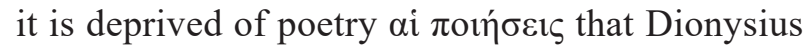
points to in Herodotus' and Thucydides' historical works (3.21; see the above-cited passage). He criticizes Philistus: he is an adulatory, menial, ignoble, his phrases ( $\varphi$ pó $\sigma 1 \varsigma$ - "turns of speech") are

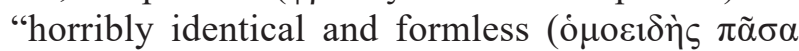

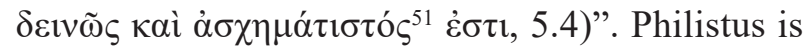

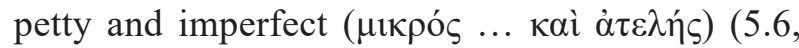
with elucidations and examples), so the philologist admits that it abhors him ( $\tau \alpha \tilde{v} \tau \alpha \delta \dot{\varepsilon} \alpha \dot{\eta} \delta \tilde{\eta} \pi \alpha$ óv

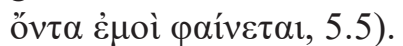

Dionysius ends this part by putting a spoonful of honey into the barrel of tar: he points out to the harmony ( $\varepsilon \dot{\sigma} \sigma \tau o \mu \mu^{\prime} \alpha$ ), a sense of proportion and rhetoricalness typical of Philistus' works. The essence of the latter "praise" (here, possibly, cum grano salis) is that, according to the philologist from Halicarnassus, Philistus' style is more suitable for speeches meant for debates in as-

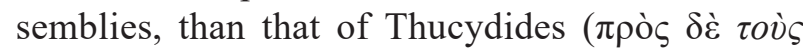

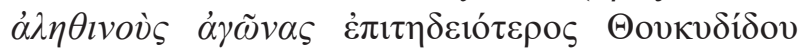
(5.6). ${ }^{52}$ Dionysius points out that Philistus' turn of phrase is more serviceable in verbal contest, in legal pleadings which are to produce an impact on the audience at a particular moment; and this by all means runs counter Thucydides' principles as expounded in methodological chapters of his "The History of the Peloponnesian War". ${ }^{53}$

Domínguez 1989: 547 sig.; Di Stefano 1993-1994; Di Vita 1999: 368, 369-370; Domínguez 2006: 289-290, 340; Sudano 2016.

50 See again I. Matijašić's remarks: Matijašić 2018:

79 ff. (also here: "Dionysius quotes a passage..., which does actually appear rather dull").

51 In this sentence Dionysius contrasts the form

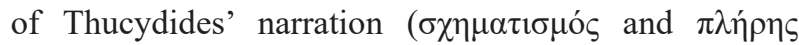

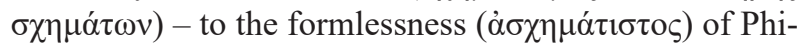
listus' expressions.

52 Discussion of this chapter of the treatise: Matijašić 2018: 79, 80-82. See also: Fromentin 2010: $103-$ 118; Osipova 2019: 830, 832.

53 Here are the proverbial lines from Thucydides: "Still, from the evidence that has been given, any one would not err who should hold the view that the state of affairs in antiquity was pretty nearly such as I have described it, not giving greater credence to the accounts, on the one hand, which the poets have put into song, adorning and amplifying their theme, and, on the other, which the chroniclers have composed with a view rather of pleasing the ear than of telling the truth, since their stories cannot be tested and most of them have from lapse of time won their way into the region of the fabulous so as to be incredible. He should regard the facts as having been made out with sufficient accuracy, on the basis vi. The last, sixth, chapter of the treatise, is devoted to Theopompus of Chios. ${ }^{54}$ Dionysius compares Xenophon to Herodotus, and Philistus to Thucydides, while Theopompus does not have a match, ${ }^{55}$ he seems to stand aloof, and the orator extols this historiographer. "As a historian, he deserves praise... for his choice of themes... arrangement of material... thoroughness and industry... multifacetedness of composition ( $\tau$ ò $\pi \mathrm{o} \lambda \hat{\mu} \mu \mathrm{o} \rho \varphi \mathrm{v}$

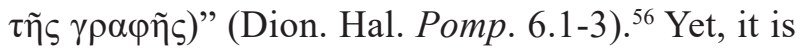
not only about Theopompus' meticulous gleaning of evidence and skilful arrangement of material, but about his philosophical comprehension of events and characters' deeds. ${ }^{57}$ So Dionysius shows him as a philosophizing historian, and "a psychologist" at that, unsurpassable by any creators in this field.

"The same may be said of the philosophical reflections scattered throughout his History, for he has many fine observations on justice, piety, and the rest of the virtues. There remains his crowning and most characteristic quality, one which is found developed with equal care and effect in no other writer, whether of the older or the younger generation. ... It is the gift of seeing and stating in each case not only what is obvious to the multitude, but of examining even the hidden motives of actions and

of the clearest indications, considering that they have to do with early times" (1.21.1; Smith 1956: 37); and ibid. 1.22.4.

54 Selected literature on Theopompus and the characteristics of this historian by Dionysius: Laqueur 1934; Borukhovich 1959; Anderson 1963; Connor 1968; Lane Fox 1986; Pédech 1989; Shrimpton 1991; Gabba 1991: 73-79; Christ 1993; Flower 1994; Hornblower 1995; Sanders 1995; Bearzot 2005; Ottone 2010a; Ottone 2010b; Chavez-Reino 2010; Parmeggiani 2014: 1-4; Vattuone 2014: 7-34; Parmeggiani 2016; Hau 2016: 258270, 271-277; Ottone 2017; Matijašić 2018: 4-5, 20-21, 51 ff., 59-61, 70-73, 78-86, 120-122, 165-172, 183 ff.

55 Scholars have noted that divergences between Theopompus and Thucydides were deliberate: Connor 1968: 106, 119-120; Hornblower 1995: n. 47 ("Theopompus' (surely deliberate) divergences from Thucydides", with reference to W.R. Connor). On parallels in the works of Thucydides and Theopompus and the "search of relations" between the two historians, see: Chavez-Reino 2010.

56 Dionysius considers the variety of the historical work in another place of this work (Pomp. 3.11-12), where Herodotus' mastership is contrasted with that of Thucydides (and, as has been said before, not to the

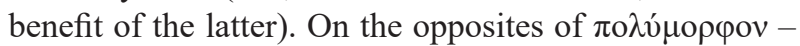

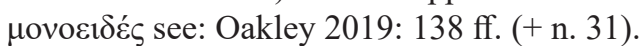

57 See Vattuone 2014: 16 ff.; Parmeggiani 2016: 400-402. 
actors and the feelings of the soul (things not easily discerned by the crowd), and of laying bare all the mysteries of seeming virtue and undiscovered vice" (Ротp. 6.6-7). ${ }^{58}$

Speaking about the ingenuity of Theopompus, Dionysius compares the historian to the "most brilliant" Athenian orators. "As to the style, he is close to that of Isocrates" $" 60.9)$, though "he differs from Isocrates in keenness and stringency" (ibid.), while "never being inferior to Demosthenes' power" (6.10). As was already noted, according to the 'scale' of Dionysius, Plato is below Demosthenes in grand style (2.8), Demosthenes emulates Thucydides (3.20), and Plato is influenced by Thucydides and Gorgias.

Having marked out many virtues of the historian of Chios, Dionysius criticizes him reservedly for inappropriate insertions $(\pi \alpha \rho \varepsilon \mu \beta o \lambda \alpha i)$, which, as often as not, Theopompus makes out of place and out of time, moreover, many of them seem to him naïve, funny and childish ( $\pi 0 \lambda \dot{v} \delta \dot{\varepsilon}$ $\tau \grave{o} \pi \alpha l \delta i \tilde{\omega} \delta \varepsilon \varsigma \dot{\varepsilon} \mu \varphi \alpha i ́ v o v \sigma \alpha 1,6.11) .{ }^{61}$ Examples of such insertions-'paidiodes' are found at the end of the book: Silenus in Macedonia and a sea monster attacking a ship; Theopompus is said to have had a lot of other nonsense stories of the same kind (ibid. 11) ${ }^{62}$ Although Dionysius admits that Theopompus' works contain many amazing and

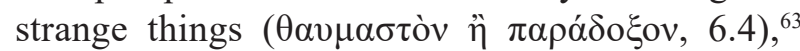
but the historian of Chios incorporates all these elements - peculiar anecdotes - not for the sake of entertainment but for practical use.

58 Roberts 1901: 123, 125.

59 Flower 1994: 52-57.

60 On Isocrates and Hellenic historiography: Marincola 2014; Matijašić 2018: 82-83, 120-121, 128$135,145-146$, et al. (on the rhetorical works of Dionysius of Halicarnassus); Viidebaum 2021 (with vast bibliography)

${ }^{61}$ Cf. Cic. De leg. 1.1.5.

${ }^{62}$ Matijašić 2018: 81.

63 As to the substantiation in Dion. Hal. Pomp. 6.4 of the significance of including into the historical work of episodes of $\theta \alpha u \mu \alpha \sigma \tau o ́ v$ and $\pi \alpha \rho \alpha ́ \delta$ o ov and of the experience of historical narration of Dionysius of Halicarnassus himself in the "Roman Antiquities", I will refer to Stephen Oakley's notes: "In the Ant. Rom. Dionysius is in fact relatively restrained in his reporting of the marvelous, coupling these words or their cognates to describe events or people at Ant. Rom. 3.13.3, 21.1, 22.10, 47.4; 4.2.3; 5.8.6; 6.13.4" (Oakley 2019: 137, n. 15$)$.

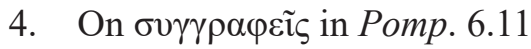

Dionysius of Halicarnassus ends his treatise on the rhetorical mastery of Ancient Greek writers with pointing out the importance of his analysis and comparison:

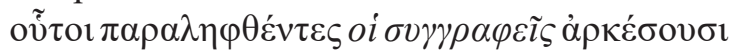

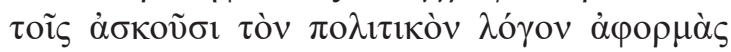

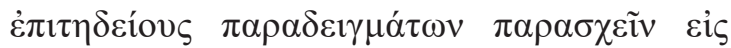

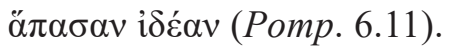

"Thus, the study of the chosen syngraphers will constitute the necessary basis for those mastering political eloquence and give examples of all types of style".

Olga V. Smyka in her Russian version renders oi $\sigma 0 \gamma \gamma \rho \alpha \varphi \varepsilon \tilde{c} \varsigma$ in this passage as "writers"; it seems that here Dionysius means not only historiographers, but also philosophers and orators, that is, all those Greek authors examined in this treatise. But the main part of Dionysius" "The Letter to Pompeius" (Chapters 3-6, which constitute 2/3 of the work) is devoted to the comparison of historians. The orator of Halicarnassus uses the words

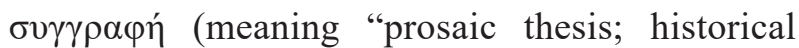

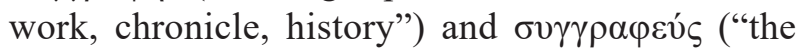
author of a prosaic work, writer; chronicler; historian") to refer to the Greek historiographers. ${ }^{64}$

In Dion. Hal. Pomp. these words occur 10 $(+1)$ times: on 5 occasions in Chapter 3 devoted to Herodotus and Thucydides, the rest $5(+1)$ are found in the last chapter (6) on Theopompus of Chios. ${ }^{65}$ Here are excerpts from the text which

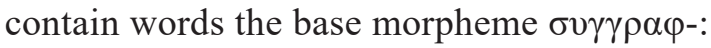

3.7: "... but from those syngraphers before him (Herodotus - A. S.) Hellanicus and Charon $(\dot{\alpha} \lambda \lambda \grave{\alpha}$

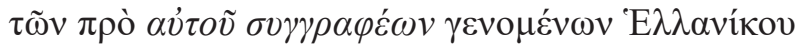

64 See dictionaries: LSJ: 1661; Pape 1908: 962, 963; Dvoretsky 1958: 1518; Diggle et al. 2021: 1297.

65 Germaine Aujac added an elucidation to the

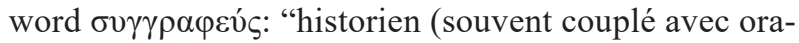
teur... et philosophe); prosateur (opposé à poète...); auteur (de manuel didactique...)" (Aujac 2002b: 272-273, for the foregoing meanings of the word here are passages from Dionysius' works as they are rendered in "Les Belles Lettres" publication of the orator; and further

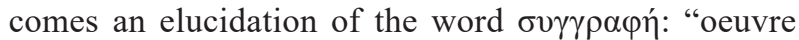
historique (de Théopompe)" (Aujac 2002b: 273, with references to two places in the sixth chapter of "The Letter to Pompeius"). See also in "The Three Literary

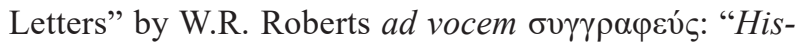

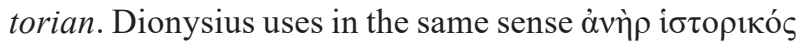
(ad Pomp. 110.4, 110.24) (with the indication of places

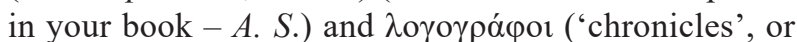
perhaps rather 'prose writers', de Comp. c. 16)" (Roberts 1901: 205). 


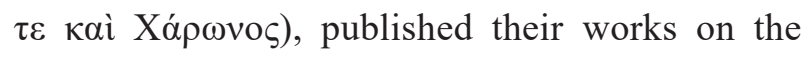
same topic"; 66

3.15: "As to the content, I will mention yet another quality that ... we wish to find in all historical

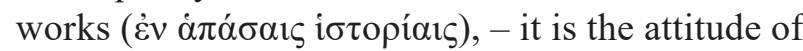
the syngrapher ( events they recount"; 67

3.18a: "The syngraphers regarding this virtue are divided: for Thucydides..., while Herodotus...

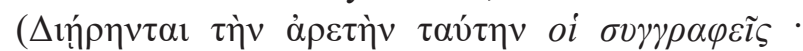

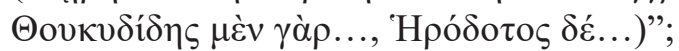

3.18b: "in these ( $\alpha$ i $\alpha \rho \varepsilon \tau \alpha i$ / virtues - A. S.)

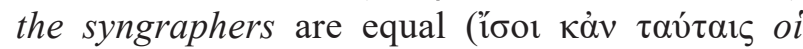

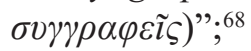

3.21: "I may have said enough about the syng-

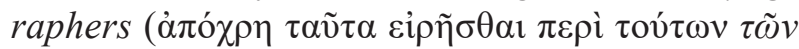
$\sigma v \gamma \gamma \rho \alpha \varphi \varepsilon ́(\omega v)$, about whom much can be said, but this is on another occasion",; 69

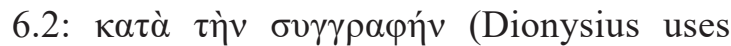
the word $\sigma v \gamma \gamma \rho \alpha \varphi \eta$ to denote the work by Theopompus, the historian of Chios, to whom the sixth chapter of the treatise is devoted);

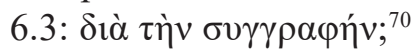

6.6a: "Indeed, all these [qualities] of the syngrapher (that is, the foregoing virtues of the historian Theopompus $-A$. S.) deserve imitation ( $\pi \alpha ́ v \tau \alpha$

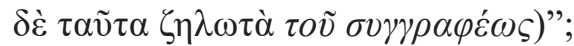

6.6b*: "philosophizing ${ }^{71}$ in the entire syngraphe on justice and devotion, and other virtues (

${ }^{66}$ See Alganza Roldán 2015: 6, 17, 18 and page 23 has a table (though the reference to the passage is not accurate: Dion. Hal. Pomp. 3.6 - sic!).

${ }^{67}$ Here Dionysius compares the attitudes of Herodotus and Thucydides to what the historian recount in

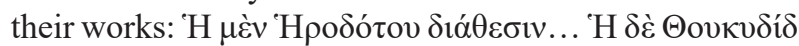

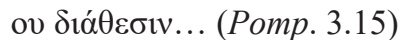

68 Both passages from $\S 18$ speak about the juxtaposition of the historians Herodotus and Thucydides.

${ }^{69}$ Dion. Hal. Pomp. 3.21 also refers to Herodotus and Thucydides - the main characters of the third chapter of "The Letter to Pompeius". This paragraph completes the first section on historiographers. Dionysius gave a detailed analysis of Thucydides' works in the treatise "On Thucydides", where he also used the comparison of Athenian author with Herodotus.

70 Again, when characterizing the principles of Theopompus' historiography, he speaks about his historical work.

71 Dionysius of Halicarnassus often uses the verb

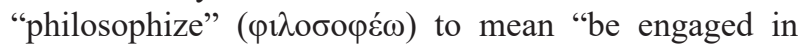
research".

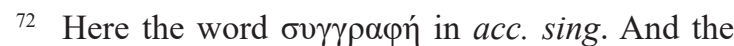
preposition $\pi \varepsilon \rho$ í are another insertion; see, for example, the edition by "Bibliotheca Teubneriana" of rhetorical

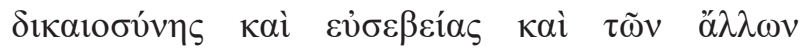

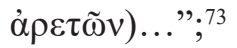

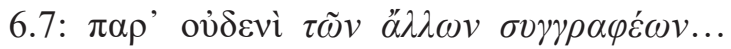

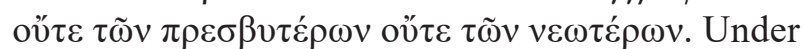
discussion is a special quality of Theopompus' works, which is not so pronounced in works of "any other syngraphers ... either those older or younger" as it is in the works by the historian from Chios. In this case, as well as in the two passages of the previous, sixth, chapter, the matter in question is not about writers in general, but of the authors of historical works.

6.11: "These syngraphers (singled out for consideration in this treatise $-A$. S.) are ample

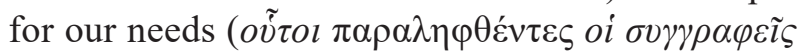

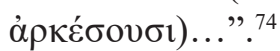

It should be noted that the words $\sigma 0 \gamma \gamma \rho \alpha \varphi \varepsilon v ́ \varsigma$

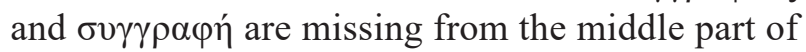
the treatise, neither are they in Chapter 4 where the author juxtaposes Xenophon with Herodotus, nor in Chapter 5 which speaks about Philistus, who is compared with Thucydides.

In "The Letter to Pompeius", Dionysius uses

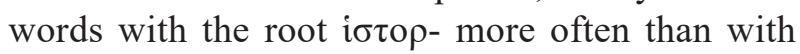
the other "historiographical" meaning. Different

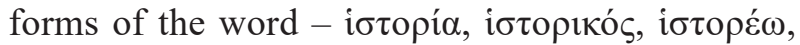

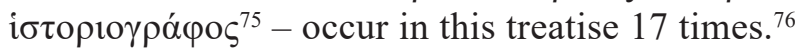
Again, the use of words beginning with i $\sigma \tau \rho \rho-$ occur only in the part that compares the works of Herodotus and Thucydides (Ch. 3), and in the last chapter of Theopompus (6). ${ }^{77}$ In the chapters devoted to the historians Xenophon and Philistus, the words meaning "historiography" (practically) never happen. Only once is it said that Xenophon "chose noble and grand themes for his historical

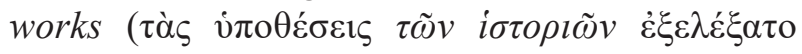

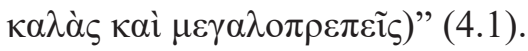

works of Dionysius, prepared by Hermann Usener (Usener, Radermacher 1929: 246, ad loc.); in a different way in the comment to this passage in an old edition of another German philologist Friedrich Sylburg: $\pi \alpha \rho$ '

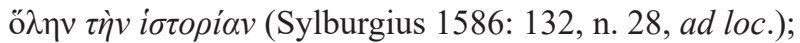
cf. G. Aujac and her references to H.C. Usener and F. Sylburg (Aujac 2002b: 98, n. ad loc.).

73 The matter in question is additional virtues of the historical work by Theopompus.

74 This sentence in translation by W.R. Roberts occurs in full at the beginning of the section.

75 Dion. Hal. Pomp. 3.1 has one reference to

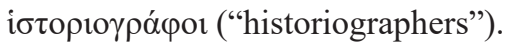

${ }_{76}$ Without the passage Pomp. 6.6, F. Sylburg referred to (see above, n. 72).

77 Except in Pomp. 1.8 and twice in chapter 4 
Dionysius regards Xenophon as an imitator of Herodotus (see above), but never does he call either Xenophon or Philistus a "syngrapher" (even if the latter can be classed among best-of-the-rest historians, which cannot be said of the former). Both the historiographers follow the pair of "fathers" of historical prose - Herodotus and Thucydides - and precede the great syngrapher, the title the orator of Halicarnassus conferred on Theopompus.

The paradox is proverbial: the historian Thucydides, who is regarded as the founder of ancient (and not only) historical science, in his his-

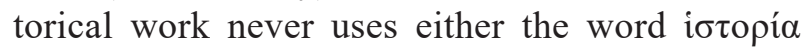
or any cognate words. Contrary, as it happens, to Herodotus, in whose works "historiographic" the lexis frequently occurs. "A Lexicon to Herodotus" by J.E. Powell features 22 occasions when different forms of the word are used. ${ }^{78}$ His younger contemporary, Thucydides, uses specifically the syngraphic (xyngraphic) vocabulary. In "The History of the Peloponnesian war" there are over 20 occasions of the words with the base morpheme $\xi v \gamma \gamma \rho \alpha \varphi-$. I will refer to the "Lexicon Thucydideum", compiled by Élie Ami Bétant; the Swiss philologist points out 16 occasions of the use of different forms of the

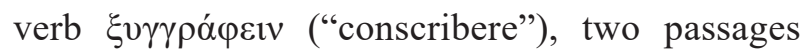

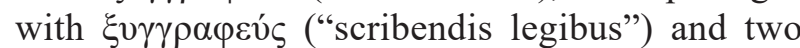

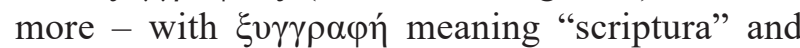
"historia". 79 Thucydides in 1.97 .2 speaks about the history of Attica written by Hellanicus ( $\dot{\varepsilon} \vee \tau \tilde{\eta}$

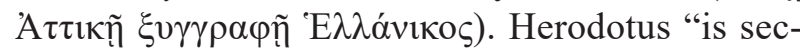
ond" to his younger fellow historian in the number of words drawn from the "syngraphic" vocabulary.

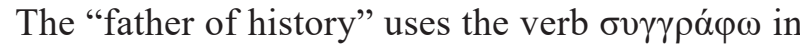
6 different forms in the meaning of "record in writ-

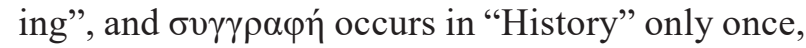
in Hdt. 1.93.1.80

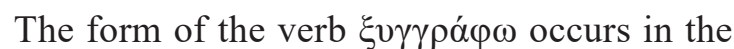
"introduction" to the work, literally, in the first line, where the historian speaks about himself and

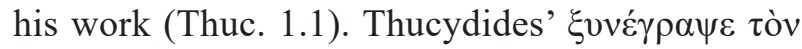
$\pi$ ó $\lambda \varepsilon \mu o v$ can be rendered as "recorded the history of war in writing". So the publishers of the work by the Athenian historian sometimes put the noun

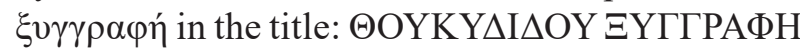
("History" by Thucydides).

Thucydides, a syngrapher par excellence, was very popular among orators and historians of the

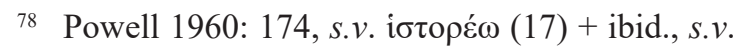

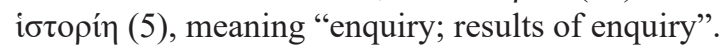

79 Bétant 1847: 177-178.

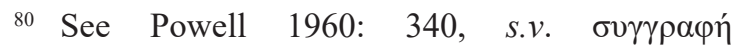
("recording"). 1st century BC. A lot of reviews written by Greek and Roman authors have survived, including that by Dionysius of Halicarnassus. I will refer to the work by Luciano Canfora, which contains ample material on Thucydides in Ancient Rome, ${ }^{81}$ with vast bibliography on the topic; as well as the article in the recent collection of papers on the reception of Thucydides. ${ }^{82}$

Judgments on Thucydides can be found in Dionysius' works "On Demosthenes" (1, 2, 4, 6, 9, 10, 15, 39), "On Lysias" $(2,3,4)$, "On Literary Composition" $(4,7,10,18,22)$ and others. ${ }^{83}$ Comments made by the orator on the mastery of the Athenian historian are often lofty. Nonetheless, Dionysius takes pride of place among Thucydides' ancient critics. As H. Sonnabend noted, "An der Spitze der Skeptiker stand der griechische Rhetor und Historiker Dionysios von Halikarnassos..." $"{ }^{\prime 4}$ C.C. de Jonge in "Dionysius of Halicarnassus on Thucydides" 85 explains the inception of this "unduly harsh judgment" passed by Dionysius on Thucydides, considering the critical attitude of the scholar of Halicarnassus toward historiography (and literature on the whole) and the principle governing accounts of history, as well as making allowances for the specifics of the then Roman audience of the 1st century BC Dionysius aimed at. The treatise under review is full of critical remarks aimed at the Athenian historian, the third chapter of which is specifically devoted to the comparison of works by Herodotus and Thucydides, and, as already was noted, almost in all cases not to the benefit of the latter.

The orator sums up his deliberations in the sentence from the finale of "The Letter to Pompeius" (6.11) which is cited at the beginning of the paragraph. This sentence begins with oṽ $\tau$ ol, the masculine demonstrative pronoun in the plural, which

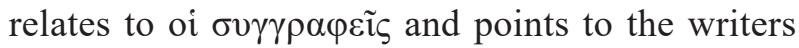

81 Canfora 2006.

82 Fromentin, Gotteland 2015, 14, 16-18, 19. On the prominence and authority of the Athenian historian, see Simon Hornblower: Hornblower 1995. See also: Wiater 2011; Iglesias-Zoido 2012; Kennedy 2018b, 608 ff., containing a survey of the Roman and Byzantine historiography on Thucydides (p. 608, n. 5 and 609, n. $6-$ citing important literature).

83 See the survey in the introduction by G. Aujac to volume 4 of "Opuscules rhétoriques" by Dionysius of Halicarnassus (Aujac 2002a: 18-33).

84 Sonnabend 2004: 83, with a reference to G. Wille's work "Zu Stil und Metode des Thukydides" (Wille 1968); cf. Sonnabend 2004: 105.

85 de Jonge 2017. 
spoken of in the text, namely, to the history-writers whom Dionysius deemed exemplary authors. Here acolytes of Clio, first and foremost, Herodotus, Thucydides, and Theopompus, are referred to as

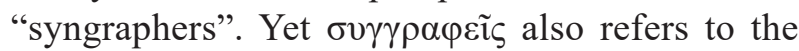
earlier historiographers - Hellanicus and Charon, and Dionysius also uses this word to describe all

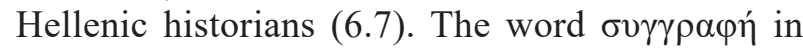
its main sense of "historical work" occurs three times in the entire corpus of Dionysius' rhetoric writings, and all the three are found in "The Letter to Pompeius", where it is used only to refer to the works of Theopompus of Chios (6.2,3 and 6b).

O.V. Smyka in her translation of The Letter to Pompeius into Russian always (except 3.21) ren-

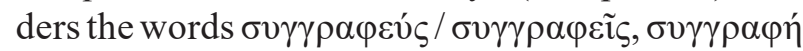
as "author", "writer" or "writers", "works" though Dionysius means historical writings and history-writers on all occasions in the treatise. Here are several examples of translations of the passage Pomp. 6.11. Thus, in the old French edition of the rhetorical works of Dionysius of Halicarnassus, the beginning of the last sentence of "The Letter" goes like this: "Tels sont les historiens..."; 86 the English version of W.R. Roberts: "The study of these historians...",87 the French edition "Les Belles Lettres": "Les historiens ici présentés..."; 88 another English translation published in the classical series Loeb Classical Library": "The comparison of these historians..." ${ }^{89}$ As we see, all the

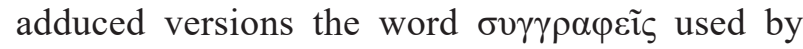
Dionysius are rendered as "historians" ("les historiens", "historians"), that is, writers whose works Dionysius analyses in chapters 3-6 of his Pomp.

I will note that in "Les Belles Lettres" collection of Dionysius" "Opuscules rhétoriques", the editor

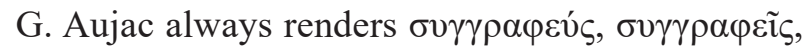

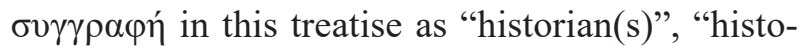
ry", "historical" ("historien, historiens, histoire, historique"). Aujac provides an explanation to

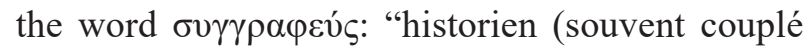
avec orateur... et philosophe); prosateur (opposé à poète...); auteur (de manuel didactique...)" ${ }^{90}$

86 Gros 1826: 135.

87 Roberts 1901: 127.

88 Aujac 2002b: 99.

89 Usher 1985: 399

90 Aujac 2002b: 272-273. The adduced meanings of the word are such that appear in the passages from Dionysius' works in "Les Belles Lettres" edition. And then

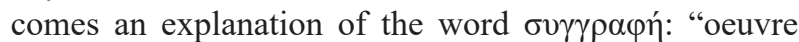
historique (de Théopompe)" (Aujac 2002b: 273), with references to the two places in the sixth chapter of the treatise.
In the rhetorical works of Dionysius apart from

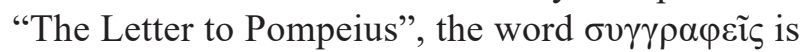
repeatedly attended by $\pi$ oin $\tau \alpha$ í, and, as the context shows, in this combination syngraphers-historians are contrasted with poets. ${ }^{91}$ I will point to several places in which this pair occurs:

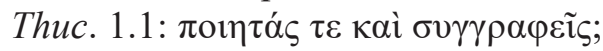

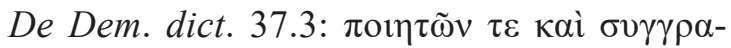

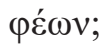

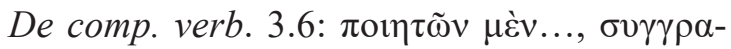
$\varphi \dot{\varepsilon} \omega \nu \delta \dot{\varepsilon} \ldots ;$

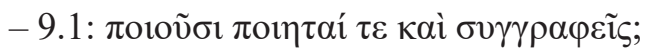

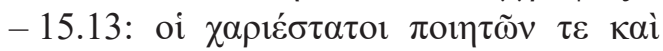

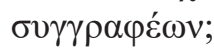

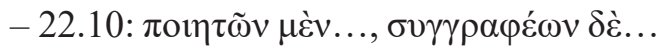

Let me direct attention to two illustrative examples in the treatise "On Literary Composition": 3.6 and 22.10. The first one singles out the poet and the syngrapher as exemplary writers, which "determines a clear understanding of the others [poets and syngraphers]":

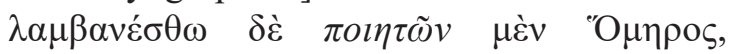

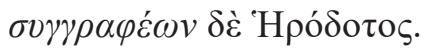

"Let us choose Homer out of poets, and Herodotus out of history-writers".

A similar construction of juxtaposing the words of interest to us occurs in Chapter 22, when Dionysius chooses $\tau \tilde{\omega} v \dot{\varepsilon} \pi \mathrm{t} \varphi \alpha v \varepsilon \sigma \tau \alpha \dot{\tau} \tau \omega \nu \dot{\alpha} v \delta \rho \tilde{\omega} v$ to discuss the two others - a poet and a syngrapher:

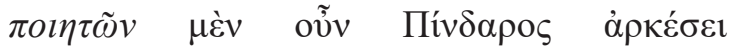

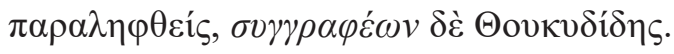

"Out of poets, Pindar will suffice, of history-writers, Thucydides".

Thus, in both cases, the great poets of Antiquity, Homer and Pindar, are contrasted with

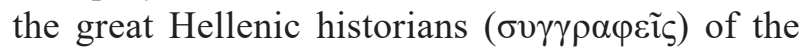
5th century BC, Herodotus and Thucydides.

Dionysius begins his work "On Thucydides"

(1.1 and 3) with the same juxtaposition:

"My earlier publications 'On imitation' ( $\pi \varepsilon \rho i$

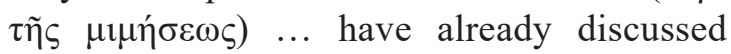

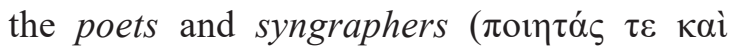

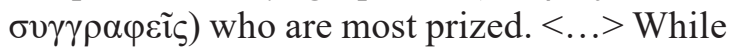

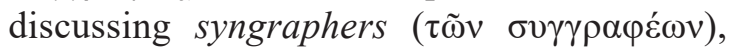
I stated my views on Thucydides, though briefly and basically".

In both cases (they are italicized in the given ci-

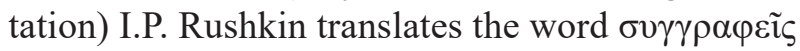
used by the orator as "historians", and what is more, the citation also has the syngrapher-historian,

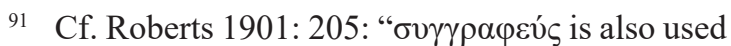
by Dionysius ... of a prose writers, as distinguished from

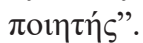


Thucydides, whom Dionysius devoted this study to. See, however, in the new French translation of the "introduction": "les poètes et les prosateurs", ${ }^{2}$ also on the second occasion (Thuc. 1.3): "au chapitre des prosateurs"; 93 compare, in Lexique general to the corpus of Dionysius' works compiled by G. Aujac:94 "prosateurs (opposé à poète)", with reference to Dion. Hal. Thuc. 1.1 and other passages where Dionysius uses this word in the meaning of "prose writer". The first sentence of the treatise "On Thucydides" S. Usher renders in English as: "poets and prose writers"; 95 compare also in Latin as translated by I.I. Reiske, ${ }^{96}$ and in English by W.K. Pritchett ("writers of poetry and prose"). 97

In the treatise "On Literary Composition", poets are paired up with logographers, thereby clearly distinct. In contemporary ancient studies, the $l o-$ cus * communis started to call the Pre-Herodotean Ionic history-writers (those who worked before or at the same time as Herodotus) "logographers". This notion has caught on and got established in our scholarship, but, in fairness, it is nothing but an historiographic construct stemming from the German classicists of the 19th century, which has nothing to do with the phenomenon it defines, that is, with the works of the "forefathers of history". Dion. Hal. De comp. verb. 16.1 says:

"Striving to visualize their object, poets and

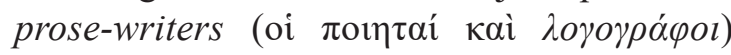
themselves coin appropriate and vivid words, as I already said, or they borrow the most representational words composed by previous writers $<\ldots>$ ".

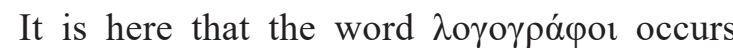
only once in the whole corpus of rhetoric works by Dionysius of Halicarnassus. This part of the treatise dwells on pleasant and eloquent speech, on melody and rhythm of poetic works, gives citations from "Iliad" and "Odyssey" by Homer, references to "Cratylus" by Plato and Theophrastus, the philosopher in the Peripatetic school (chapters 15-17), and then the orator proceeds to discuss the rhythm of the works of Thucydides, Plato, Demosthenes and other writers (ch. 18). In the excerpt cited,

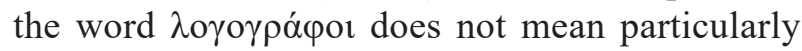

92 Aujac 2002a: 43.

93 Aujac 2002a: 43.

94 Aujac 2002b: 273, ad loc.

95 Usher 1974: 463.

96 Reiske 1777: 810.

97 Pritchett 1975: 1. But see W.K. Pritchett's com-

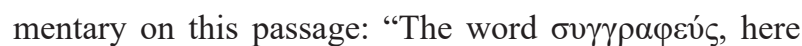
used for a prose-writer, sometimes means 'historian' in Dionysius" (Pritchett 1975: 47, n. 4). the "forefathers of history" (whom Dionysius him-

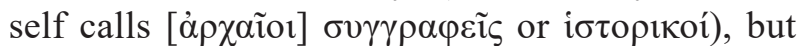
all writers of prose (cf. in the English version of this place: "The poets and prose-writers..."). ${ }^{98}$

In places where Dionysius speaks about writers of prose and not poets, juxtaposing, for example, orators with syngraphers, the latter are supposed to be history-writers (in fact, in the last two cases, the context does not allow for asserting this expressly). Thus, in the work "On the ancient orators", Dionysius claims that he is determined to examine the works of "the most outstanding of the ancient orators and syngraphers ( $\dot{\alpha} \xi 10 \lambda \mathrm{o} \gamma \omega \dot{\tau} \tau \alpha \tau \mathrm{ol}$

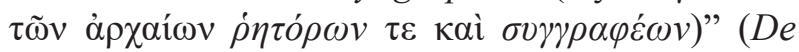
ant. orat. 4). Such distinction between prose-authors also occurs at the beginning of "The Second Letter to Ammaeus", where the scholar deliberates about Thucydides, and where syngraphers are separated from orators:

"I thought I had sufficiently indicated the characteristics of Thucydides when describing the most important and remarkable of those peculiarities which seemed to me to distinguish him from all previous orators and historians"

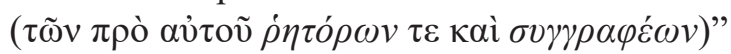
(Dion. Hal. Amm. II. 1.1) ${ }^{99}$

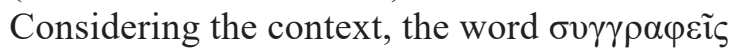
means not "writers" in general, but particularly history-writers, who stand apart from orators; the latter are, surely, writers, but working in a different genre of literature. Cf., for example, the translation of this passage done by G. Aujac: "des orateurs et des historiens"; ${ }^{100}$ but differently by I.I. Reiske: "oratoribus et scriptoribus". ${ }^{101}$ In this "Letter to Ammaeus" Thucydides is frequently referred to as a "syngrapher".

Coming back from "The Second Letter to Ammaeus" to the main subject under discussion "The Letter to Pompeius", I will note that in this

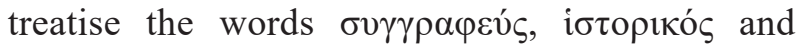

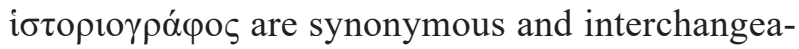
ble. It seems that Dionysius sometimes 'alternates'

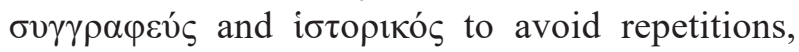
when he uses words having similar "historiographic" meanings one after another. ${ }^{102}$

98 Roberts 1910: 159. Cf. Roberts 1901: 205:

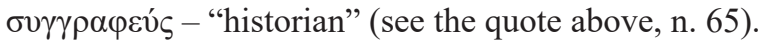

99 Roberts 1910: 131.

100 Aujac 2002a: 129.

101 Reiske 1777: 788.

102 As, for example, is the case in Pomp. 3.15: \& $\mathrm{k}$

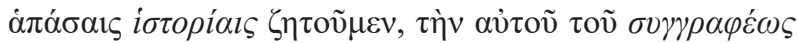
$\delta i \alpha ́ \theta \varepsilon \sigma ı v, \kappa \tau \lambda$. 
5. A remark on the historiographical "archaeology" in Dionysius' treatise

At the beginning of Pomp. 3, setting about analysing the works of historians, the philologist from Halicarnassus mentions his three studies of imitation $(\pi \varepsilon \rho \grave{\lambda} \mu \mu \eta \dot{\sigma} \sigma \varepsilon \omega \varsigma)$; the second one devoted to the analysis of "which poets, philosophers, historiographers and orators should be imitated ( $\pi \varepsilon \rho i$

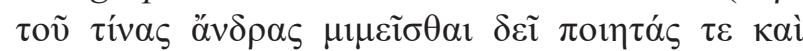

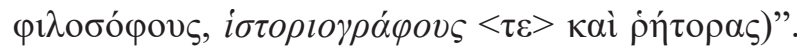
Poets $(\pi \circ \eta \eta \tau i ́)$ are treated en masse here, while authors of prose works are divided in accordance with literary genres: philosophic, historical and rhetorical.

The treatise does not dwell on poets, only twice does it mention Homer: also this epic poet appears in the context of Plato and Herodotus; ${ }^{103}$ and the orator, in support of the authoritative assertion made by the ancient poet when he criticizes Thucydides for his superabundance which "drives the reader to exhaustion", adduces the well-known quotation from Pindar (Dion. Hal. Pomp. $3.12=$ Pind. Nem. 7.52). In the second chapter, Dionysius criticizes Plato for "poetic frillings", inappropriate in prose works, yet, in another place (Pomp. 3.21), he points out that he regards Herodotus' and

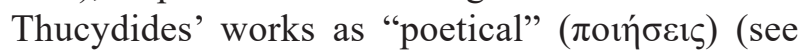
the above quotation).

This theoretical work presents a detailed analysis of works of the best historians of the $5^{\text {th }}$ and $4^{\text {th }}$ centuries $\mathrm{BC}-$ "persons worthy of imitat-

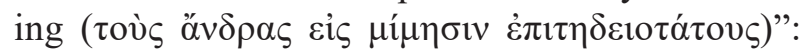
Herodotus, Thucydides, Xenophon, Philistus and Theopompus (ibid.). According to the critic, they were the first and the last great historiographers of the past. Dionysius holds that the decline in literature started in the $4^{\text {th }}$ century BC, after Alexander the Great. So the time of exemplary style is confined to the classic age when there were true masters. ${ }^{104}$ The note of the time of Alexander, whose deeds had become the dividing line between epochs (and, in a broad sense, political and cultural senses, and in rhetoric and literature, in particular), occurs at the beginning of Dionysius' treatise

103 Dion. Hal. Pomp. 1.13, where the Athenian historian is called a critic of Homer, and 3.11, where the "father of history" is called an imitator of the Poet, the "fore-historian".

104 Russell 2012, 460: "He (Dionysius of Halicarnassus $-A$. $S$.) doubtless thought of it as exemplifying his literary teaching, which was directed towards restoring Classical prose after what he saw as the aberrations of the Hellenistic period".
"On Ancient Orators". ${ }^{105}$ In "The Letter to Pompeius", the critic does not mention this divide, but even here he contemplates only classic writers.

In another treatise, Dionysius describes the history of Hellenic literature as stages in the regression of style: he distinguishes ancient writers ( $\dot{\alpha} \rho \chi \alpha i o 1)$, later ( $\mu \varepsilon \tau \alpha \gamma \varepsilon \sigma \tau \varepsilon \dot{\varepsilon} \rho \circ)$ and the latest

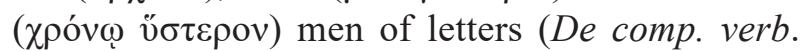
4.29-31). Here the scholar of Halicarnassus names still later historians who worked after the end of the 4th century BC, largely those of the 3rd-2nd centuries BC: Phylarchus, Duris, Polybius, Psaon, Demetrius of Callatium, Hieronymus, Antilochus, Heraclidus, Hegesias of Magnesia and "a host of

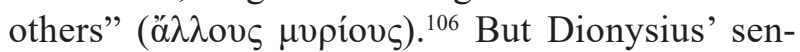
tence is harsh: it takes a great effort even to read the works by Hellenistic authors up to the end, and all of them are unworthy of imitating owing to their disgraceful style. ${ }^{107}$

Thus, by analysing the historical works ö $v \delta \rho \varepsilon \varsigma$

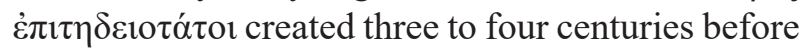
his time in "The Letters to Pompeius", Dionysius seems to be making a peculiar experiment in theoretical "archaeology". ${ }^{108} \mathrm{He}$ analyses not only historical works, but also a wide range of texts written by philosophers and orators, since the treatise discusses issues of style of the classic authors (predominantly, the Attic ones), and Chapters 1 and 2 of "The Letter to Pompeius" can be called "Platonian".

105 Dion. Hal. De ant. orat. 1. On periodization by Dionysius of classical early historiography: Alganza Roldán 2015: 7, 9, 18. See article by C.C. de Jonge "The Attic Muse and the Asian Harlot" (2014); cf. de Jonge, Hunter 2019: 5 ("The Attic Muse, which had been driven away by an Asian harlot after the death of Alexander the Great...”), 19, 20. See Sobolevsky 1960: 158-160 (here p. 158: "But 'the Attic Muse' went silent, as Dionysius says, after the death of Alexander the Macedonian (323 $\mathrm{BC})$, to be more exact, with the deaths of Demosthenes and Hyperides (322 BC), that is, 300 years before Dionysius”); Osipova 2009: 462 ff.; Yunis 2019: 87: “...into an epochal narrative of original glory (classical Athens), descent into depravity and chaos (Hellenistic Asianism following Alexander's death)..." On the discussion on Classicism, Atticism, and Asianism: Gelzer 1979; additionally: Hidber 1996; Reid 1996; de Jonge 2008; Wiater 2011; Wiater 2018; de Jonge, Hunter 2019: 18-21 (with literature review); Yunis 2019; de Jonge 2019.

106 Dion. Hal. De comp. verb. 4.30. Dionysius here is hyperbolizing: "A day would not be enough for me to name all the historians (later historians who are inferior to the predecessors $\alpha \rho \chi \alpha i ́$ i $-A$. S.)".

107 Osipova 2009: 462; Matijašić 2018: 73, 85 f., 115, 214 f., n. 124; Osipova 2019: 829, 830 (and n. 3).

108 Sobolevsky 1960: 159 (+ n. 12), 160. 
Dionysius is convinced that - like the work, like its author - every historiographer exposes himself as a sincere, fair, moral and reasonable man or, the opposite, thereby revealing his different qualities. Every historical work is bound to reveal the personal predilections of its author. ${ }^{109}$ And the rhetorical and philological "archeology" by Dionysius of Halicarnassus seems to show not only his scholarly interest in analysis of the writers of the past, but a focus on the present, both in literary and cultural aspects.

\section{The protracted literary agon}

This work does not touch upon problems of the ingenuity of Dionysius' assertions, the principles of his literary criticism, the dichotomy of rhetoric and historiography in the works of the scholar of Halicarnassus, ${ }^{110}$ the problems of classicism in literature, nor literary theory during the age of Augustus. ${ }^{111}$ Having briefly delineating the structure of "The Letter to Pompeius" and the sequence of comparisons made by the author who has surpassed all the ancient historians before him, proceeding from the text of this work, I will focus on one point.

Thus, in the treatise under study, Dionysius not only discusses the various styles of the writers of the $5^{\text {th }}$ and $4^{\text {th }}$ centuries $\mathrm{BC}$, but he also juxtaposes and assesses them, distinguishing their strong and weak sides. Plato, in the critic's opinion, is inferior to Demosthenes in his loftiness of style (2.8), Demosthenes imitates Thucydides (3.20), Plato is under the influence of Gorgias and Thucydides, while Thucydides, according to the critic, is inferior to Herodotus in his mastery. ${ }^{112}$ As for the philosophizing historian, Xenophon, he simply is not up to Thucydides and Herodotus. ${ }^{113}$ According to

109 Dion. Hal. Pomp. 3.15; and cf. Id. Thuc. 8.2.

110 For discussion of rhetoric and historiography in Antiquity (beyond Dionysius of Halicarnassus), see the interesting work by S. Schorn: Schorn 2019, 627-654. In relation to Dionysius' views': Meins 2019; Viidebaum 2021.

111 See Wiater 2011; Hunter 2019; Wiater 2019.

112 Grube 1950; Grube 1965, 209-211.

113 Clemence Schultze notes: "As regards the depiction $\left(\mu \dot{i}_{\mu \eta \sigma \varsigma \varsigma)}\right.$ of emotion and of character, Dionysius awards Thucydides the palm for the former, Herodotus for the latter (Pomp. 3.18). Xenophon falls short here (Pomp. 4.4), while Theopompus' understanding of 'the emotions of the soul' is outstanding (Pomp. 6.7-8)" (Schultze 2019, 178). the grading scheme devised by Dionysius (who was surely aware of the full texts by the early-Ionic syngraphers, the "forefathers of history", and the critic could compare the texts), the works by the "father of history" excel the works by Charon and Hellanicus, while Theopompus' art of style is on par with that of Demosthenes and is superior to that of Isocrates - the two "most brilliant" orators of the past.

It seems as if by engaging with a whole gallery of personalities, Dionysius presents an agon of writers, their styles, the right choices of topics, the extent of tenseness of narration, obligatory digressions from the main topic, the skill of weaving these excursions into the story-line, etc. The author does not use the word agon, but the verbal form containing the root $\dot{\alpha} \gamma \tilde{\omega} v-$ occurs when related to the historical work by Thucydides (in the cited passage 5.6. above). But the text is abundant in comparative forms when it comes to the examination of writers. Analysis of the mastery of the writers selected in the treatise is abundant in com-

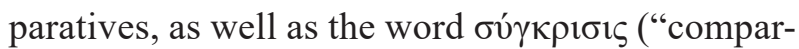

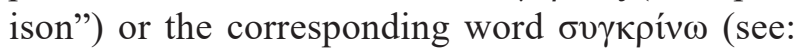
$1.8,9.11,17)$. Dionysius keeps speaking of the need for examination by comparing poetic, historical and philosophical works, laws, teachings, state systems and the rest, and in Pomp. 1.9 he states that "the best way of examination is that of

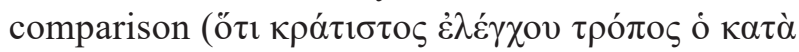

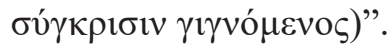

In another critical work that is devoted specifically to Thucydides, Dionysius, when characterizing the general traits of early syngraphers, "all the historians before Thucydides ( $\pi \dot{\alpha} \nu \tau \varepsilon \varsigma$ oi $\pi \rho$ ò

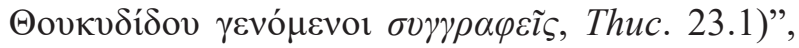
notes that they all lose to Herodotus, ${ }^{114}$ whose work is a pinnacle of the Hellenic historiography, but which, however, is devoid of the agonality ( $\xi_{\xi} \xi \tau \tilde{\omega} \nu \dot{\varepsilon} v \alpha \gamma \omega v i ́ \omega v$, ibid. 23. 8). ${ }^{115}$

One of the substantial reproaches Dionysius heaps on Thucydides and Philistus is that these historians choose specific, local, petty topics, they are

114 In a similar vein, in the same work: Dion. Hal. Thuc. 5.4-5.

115 See comments on this passage: Pritchett 1975, 82-83, n. 36 ad loc. Dion. Hal. Thuc. 23, with a reference to the article on Herodotus in $O C D^{2}(\S 11)$, whose authors compare the style of the "father of history" to the effortless ease of the Austrian genius, Mozart: "Herodotus has suffered the fate which befell Mozart. His charm, wit, and effortless ease have diverted attention from the note of profound sadness and pity sounded not seldom in his History" (Denniston, Pearson 1970, 509). 
interested in local history, narrowed down to a particular story (as, for example, the Peloponnesian War for Thucydides, who participated in it and was an eye-witness); they do not create ambitious works on "world" history, which would have described international affairs and encompassed a long period of time, the way Herodotus and other historiographers did. But Herodotus includes various digressions in his epic narration, as does Homer (Dion. Hal. Pomp. 3.11).

The grammarian of Halicarnassus presents in his work not the stringent and spiteful "Zoilus' criticism", which had been formed by the Greek and Roman scholars by the $1^{\text {st }}$ century BC, but he advocates for an objective analysis and agonistics based on the conditions that are equal for every orators of the past and the present. And Zoilus, the infamous denigrator of Homer and Plato, in Dionysius' view, becomes a competitor of the endless literary contention. Dionysius is not a "Platonomastix" or "Thucydidomastix", but by pointing out the weak points (in his understanding) in the works of his great predecessors, he positions himself as a researcher - attentive, stern, and unprejudiced. And his approach is utterly critical. Collating $\dot{\alpha} \gamma \alpha \theta$ ov̀ $\varsigma$

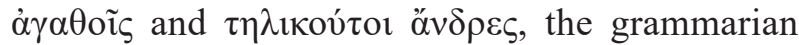
participates in this agon.

Dionysius' work is not a philological "archaeology", in the sense of studying antiquities (be they the worthiest, classic) for their own sake, since the author always aims at topical polemics. The "Roman Antiquities" by Dionysius of Halicarnassus had become the actual embodiment of the contest with the worthiest Greek historians.

Presenting a gallery of classical authors, the orator from Halicarnassus seems to compete with the great creators of the past. He portrays the adeptness in verbal artistry as a peculiar protracted agon threading across ages and epochs, a contest of historians, philosophers and orators. Dionysius narrows the circle of best writers and steps into it himself. An agonist of a critic, he states that in scholarly rhetoric "the truth is dearer", and puts forward the criteria to be applied to judge his ancient counterparts. Dionysius himself must have realized that he would be judged by the same (his own) criteria.

\section{Abbreviations}

\section{AMA}

BMCR

ClAnt

$\mathrm{CPh}$

CQ

$\mathrm{CR}$

FgrHist

GR

GRBS

ICS

IJaKF

JHS

JRS

$\mathrm{KP}$

LSJ

NP

$\mathrm{OCD}^{2}$

$\mathrm{OCD}^{3}$

$\mathrm{OCD}^{4}$

RE

\footnotetext{
$\begin{array}{ll}\mathrm{AAL} & \text { Acta Archaeologica Lodziensia, Łódź. } \\ \mathrm{AJPh} & \text { American Journal of Philology, Balti- }\end{array}$

$\begin{array}{ll}\mathrm{AAL} & \text { Acta Archaeologica Lodziensia, Łódź. } \\ \mathrm{AJPh} & \text { American Journal of Philology, Balti- }\end{array}$

$\begin{array}{ll}\mathrm{AAL} & \text { Acta Archaeologica Lodziensia, Łódź. } \\ \mathrm{AJPh} & \text { American Journal of Philology, Balti- }\end{array}$

$\begin{array}{ll}\mathrm{AAL} & \text { Acta Archaeologica Lodziensia, Lódź. } \\ \mathrm{AJPh} & \text { American Journal of Philology, Balti- }\end{array}$ more, MD.
}

Antichnyi mir $i$ arkheologiia (Ancient World and Archaeology), Saratov.

Bryn Mawr Classical Review.

Classical Antiquity, Berkeley, CA.

Classical Philology.

Classical Quarterly, Oxford.

Classical Review.

Die Fragmente der griechischen Historiker. F. Jacoby (hrsg.). Berlin; Leiden, 1923-1958.

Greece \& Rome.

Greek, Roman and Byzantine Studies, Durham.

Illinois classical Studies.

Indoevropeiskoe jazykoznanie i klassicheskaja filologija. Materiaky chtenij, posvjashchennykh pamjati professor I.M. Tronskogo (Indo-European Linguistics and Classical Philology. Proceedings of the Conference in Memory of Professor Joseph M. Tronsky). St. Petersburg.

Journal of Hellenic Studies, London. Journal of Roman Studies, London.

Der kleine Pauly: Lexikon der Antike. K. Ziegler, W. Sontheimer (hrsg.). Stuttgart. Bd. 1-5.

Greek-English Lexicon. 9th ed. With Revised Supplement Compiled by H.G. Liddell and R. Scott; Revised and augmented throughout by $\mathrm{Sir}$ H.S. Jones; with the Assistance of R. McKenzie and with the Cooperation of Many Scholars. New Supplement. Oxford.

Der neue Pauly: Enzyklopädie der Antike. H. Cancik, H. Schneider (hrsg.). Stuttgart; Weimar. Bd. 1-19.

The Oxford Classical Dictionary. 2nd ed. N.G.L. Hammond, H.H. Scullard (eds.). Oxford, 1970.

The Oxford Classical Dictionary. 3rd ed. S. Hornblower, A. Spawforth (eds.). Oxford, 1996.

The Oxford Classical Dictionary. 4th ed. S. Hornblower, A. Spawforth, and E. Eidinow (eds.). Oxford, 2012.

Platonovskie issledovanija (Platonic Investigations). Moscow; St. Petersburg.

Paulys Realencyclopädie der classischen Altertumswissenschaft. Neue Bearbeitung begonnen von G. Wissowa. W. Kroll u.a. (hrsg.). Stuttgart; München, 1893-1980. 
TAPhA Transactions of the American Philological Association.

TPAPhA Transactions and Proceedings of the American Philological Association.

VDI Vestnik drevnei istorii (Journal of Ancient History), Moscow.

\section{Literature}

Sources and Commentaries

Aujac G. 2002a. Denys d'Halicarnasse. Opuscules rhétoriques. T. 4: Thucydide. Seconde Lettre à Ammée (texte établi et traduit par G. Aujac). $3 \mathrm{e}$ tirage. Paris $(=1991)$.

Aujac G. 2002b. Denys d'Halicarnasse. Opuscules rhétoriques. T. 5: L'imitation (fragments, Épitomé). Première Lettre à Ammée. Lettre à Pompée Géminos. Dinarque (texte établi et traduit par G. Aujac). 3e tirage. Paris (= 1992).

Classen, J., Steup Ju. 1912. Thukydides (erklärt von J. Classen, bearb. von Ju. Steup). Bd. 5. 4. Aufl. Berlin (repr. 1963).

Fornaro S. 1997. Dionisio di Alicarnasso. Epistola a Pompeo Gemino. Introduzione e Commento. Stuttgart; Leipzig.

Godley A.D. 1975. Herodotus (trans. by A.D. Godley). Vol. 1. Cambridge, MA; London $(=1920)$.

Gomme A.W. 1956a. A Historical Commentary on Thucydides. Vol. 2. Oxford.

Gomme A.W. 1956b. A Historical Commentary on Thucydides. Vol. 3. 24. Oxford.

Gros E. 1826. Denys d'Halicarnasse. Examen critique des plus célèbres écrivains de la Grèce (traduit en français la première fois, avec des notes et texte en regard, collationné sur les manuscrits de la bibliothèque du roi et sur les meilleures éditions par E. Gros). T. 2. Paris.

Hornblower S. 1991. A Commentary on Thucydides. Vol. 1. Oxford.

Hornblower S. 1996. A Commentary on Thucydides. Vol. 2. Oxford.

Pritchett W.K. 1975. Dionysius of Halicarnassus: On Thucydides (trans. and comm. by W.K. Pritchett). Berkeley; Los Angeles; London.

Reiske I.I. 1777. Dionysii Halicarnassensis opera omnia. Graece et Latine (cun annotationibus H. Stephani, F. Sylburgii, F. Porti, I. Casauboni, F. Ursini, H. Valesii, I. Hudsoni et I.I. Reiske). Vol. 6: Ex scriptis rhetoricis et criticis Epistolam Primam ad Ammaeum, Epistolam ad Cn. Pompeium, Epistolam Secundam ad Ammaeum, Iudicium de Thucydidis historiis, et Librum de Admiranda vidicendi in Demosthene (curavit I.I. Reiske). Lipsiae.
Roberts W.R. 1901. Dionysius of Halicarnassus. The Three Literary Letters (Ep. ad Ammaeum I, Ep. ad Pompeium, Ep. ad Ammaeum II) (the Greek text edited with English translation, facsimile, notes, glossary of rhetorical and grammatical terms, bibliography, and introductory essay on Dionysius as a literacy critic by W.R. Roberts). Cambridge.

Rushkin I.P. 2014. Dionisij Galikarnasskij. "O Fikidide". S prilozheniem "Vtorogo pis'ma k Ammeju" [Dionysius of Halicarnassus. On Thucydides. The Second Letter to Ammaeus] (trans. and comm. by I.P. Rushkin). Aristej 9, 185-256 (in Russian).

Smith Ch.F. 1956. Thucydides. History of the Peloponnesian war (trans. by Ch.F. Smith). Vol. 1. London; Cambridge, MA (1919).

Smyka O.V. 1978. Dionisij Galikarnasskij. Pis'mo Pompeju [Dionysius of Halicarnassus. Letters to Pompeius] (trans. by O.V. Smyka). In: A.A. Takho-Godi (ed.), Antichnye ritoriki $[\mathrm{An}$ cient rhetoricians]. Moscow, 222-233.

Sylburgius F. 1586. Dionysii Halicarnassei scripta quae exstant, omnia, et historica, et rhetorica. Vol. 2: Rhetoricos eius et criticos libros continens, duobus tractatibus nusquam ante vulgatis auctus (opera et studio F. Sylburgii Veterensis). Francofurdi.

Usener H., Radermacher L. 1929. Dionysii Halicarnasei quae extant. Vol. VI: Opuscula II. Lipsiae.

Usher S. 1974. Dionysius of Halicarnassus. Critical Essays: in 2 volumes (trans. by S. Usher). Vol. 1: Ancient Orators. Lysias. Isocrates. Isaeus. Demosthenes. Thucydides. Cambridge, MA; London.

Usher S. 1985. Dionysius of Halicarnassus. Critical Essays: in 2 volumes (trans. by S. Usher). Vol. 2: On Literary Composition. Dinarchus. Letters to Ammaeus and Pompeius. Cambridge, MA; London.

\section{Research and Dictionaries}

Adkins A.W.H. 1996. The "Speech of Lysias" in Plato's "Phaedrus". In: R.B. Louden, P. Schollmeier (eds.), The Greeks and Us: Essays in Honor of A.W.H. Adkins. Chicago, 224-240.

Alganza Roldán M. 2012. Hecateo de Mileto, "historiador" y "mitógrafo". Florentia Iliberritana: Revista de estudios de antigüedad clásica 23, 23-44.

Alganza Roldán M. 2015. Historiadores, logógrafos o mitógrafos? (Sobre la recepción de Hecateo, Ferécides y Helánico). Polymnia 1, 3-24. 
Ambaglio D. 1980. Opera storiografica di Ellanico di Lesbo. Pisa.

Anderson W.S. 1963. Pompey, his Friends and the Literature of the First Century B.C. Berkeley.

Apfel H.V. 1938. Homeric Criticism in the Fourth Century B.C. TAPhA 69, 245-258.

Baragwanath E., de Bakker M. (eds.) 2012. Myth, Truth, and Narrative in Herodotus. Oxford.

Barton J. 2006. The War That Still Goes On: Adapted from Thucydides' History of the Peloponnesian War and Plato's Dialogue with Alcibiades. London.

Baurain-Rebillard L. 2016. Thésée, le rapt d'Hélène et Hellanicos: les origines politiques d'une réprobation morale. In: L. Baurain-Rebillard (éd.), Héros grecs à travers le temps: autour de Persée, Thésée, Cadmos, et Bellérophon. Actes du colloque de Metz, 28-30 mai 2015, Centre de recherches universitaires Lorrain d'Histoire 58. Metz, 213-232.

Bearzot C. 2005. Polibio e Teopompo: osservazioni di metodo e giudizio morale. In: G. Schepens, J. Bollansée (eds.), The Shadow of Polybius. Intertextuality as a Research Tool in Greek Historiography: Proceedings of the International Colloquium, Leuven, 21-22 September 2001. Leuven, 55-71.

Beer B. 2019. Rhetorik des Hellenismus: Von Theophrast bis Philodem. In: M. Erler, Chr. Tornau (hrsg.), Handbuch Antike Rhetorik. Berlin; Boston, 361-382.

Bétant É.-A. 1847. Lexicon Thucydideum. Vol. 2. Genevae.

Boedeker D. 1988. Protesilaos and the End of Herodotus' 'Histories'. ClAnt 7/1, 30-48.

Boedeker D. 2002. Epic Heritage and Mythical Patterns in Herodotus. In: E.J. Bakker, I.J.F. de Jong, H. van Wees (eds.), Brill's Companion to Herodotus. Leiden; Boston; Köln, 97-116.

Bonner S.F. 1939. The Literary Treatises of Dionysius of Halicarnassus. A Study in the Development of Critical Method. Cambridge (=2013).

Borukhovich V.G. 1959. Politicheskie vzgljady Feopompa [The Political Views of Theopompus]. Uchenye zapiski Gorkovskogo gosudarstvennogo universiteta. Serija istoricheskaja [Bulletin of Gorky State University. Series History] 46, 189-197 (in Russian).

Borukhovich V.G. 1982. Istorija drevnegrecheskoj literatury [The History of Ancient Greek Literature]. 2 ed. Saratov (in Russian).

Branham R.B. 1996. Defacing the Currency: Diogenes' Rhetoric and the Invention of Cynicism. In: R.B. Branham, M.-O. Goulet-Cazé (eds.), The Cynics. The Cynic Movement in Antiquity and its Legacy. Berkeley; Los Angeles; London, 81-104.

Bryan J. 2021. The Role of Lysias' Speech in Plato's 'Phaedrus'. Cambridge Classical Journal 67, 1-21.

Buccioni E. 2007. Keeping it secret: reconsidering Lysias' speech in Plato's 'Phaedrus'. Phoenix 61, 15-38.

Buffière F. 1956. Les mythes d'Homère et la pensée grecque. Paris.

Burrow C. 2019. Imitating Authors. Plato to Futurity. Oxford.

Canfora L. 2006. Thucydides in Rome and Late Antiquity. In: A. Rengakos, A. Tsakmakis (eds.), Brill's Companion to Thucydides. Leiden; Boston, 721-753.

Chavez-Reino A.L. 2010. À l'affût des rapports Théopompe-Thucydide: quelques éléments de repérage. In: V. Fromentin, S. Gotteland, P. Payen (eds.), Ombres de Thucydide. La Réception de l'historien, de l'Antiquité au XXe siècle. Actes des colloques de Bordeaux, les 16-17 mars 2007, de Bordeaux, les 30-31 mai 2008 et Toulouse, les 23-25 octobre 2008. Bordeaux, 327-342.

Christ M.R. 1993. Theopompus and Herodotus: A Reassessment. $C Q 43 / 1,47-52$.

Christ W. 1889. Geschichte der griechischen Litteratur bis auf die Zeit Justinians. München.

Condilo C. 2017. Agonistic Intertextuality: Herodotus' Engagement with Hecataeus on Genealogies. Journal of Ancient History 5/2, 228-279.

Connor W.R. 1968. Theopompus and Fifth-Century Athens. Cambridge, MA.

de Jonge C.C. 2005. Dionysius of Halicarnassus and the Method of Metathesis. CQ 55/2, 463-480.

de Jonge C.C. 2008. Between Grammar and Rhetoric. Dionysius of Halicarnassus on Language, Linguistics and Literature. Leiden; Boston.

de Jonge C.C. 2014. The Attic Muse and the Asian Harlot: Classicizing Allegories in Dionysius and Longinus. In: J. Ker, C. Pieper (eds.), Valuing the Past in the Greco-Roman World. Leiden; Boston, 388-409.

de Jonge C.C. 2017. Dionysius of Halicarnassus on Thucydides. In: R.K. Balot, S. Forsdyke, E. Foster (eds.), The Oxford Handbook of Thucydides. Oxford, 641-658.

de Jonge C.C. 2019. Dionysius and Horace: Composition in Augustan Rome In: R.L. Hunter, C.C. de Jonge (eds.), Dionysius of Halicarnassus and Augustan Rome: Rhetoric, Criticism and Historiography. Cambridge, 242-266.

de Jonge C.C., Hunter R. 2019. Introduction In: R.L. Hunter, C.C. de Jonge (eds.), Dionysius of 
Halicarnassus and Augustan Rome: Rhetoric, Criticism and Historiography. Cambridge, 1-33.

Denniston J.D., Pearson L. 1970. Herodotus [11]. $O C D^{2}, 509$.

Desmond W. 2004. Punishments and the Conclusion of Herodotus' Histories. GRBS 44/1, 19-40.

Dewald C. 1997. Wanton Kings, Pickled Heroes, and Gnomic Founding Fathers: Strategies of Meaning at the End of Herodotus' Histories. In: D.H. Roberts, F.M. Dunn, D. Fowler (eds.), Classical Closure: Reading the End in Greek and Latin Literature. Princeton, 62-82.

Dewald C. 2005. Thucydides' War Narrative. A Structural Study. Berkeley; Los Angeles; London.

Di Stefano G. 1988-1989. Indigeni e greci nell'entroterra di Camarina. Kokalos: Studi pubblicati dall'Istituto di storia antica dell'Università di Palermo, 34-35/1(1), 89-105.

Di Stefano G. 1993-1994. Il relitto di Punta Braccetto (Camarina), gli emporia e i relitti di età arcaica lungo la costa meridionale della Sicilia. Kokalos: Studi pubblicati dall'Istituto di storia antica dell'Università di Palermo, 39-40/1(1), 111-133.

Di Vita A. 1999. Siracusa, Camarina, Selinunte: quale frontiera? Confini e frontiera nella Grecità d'Occidente, Atti del trentasettesimo Convegno di Studi sulla Magna Grecia. Taranto 3-6 ottobre 1997. Napoli, 361-379.

Diggle et al. 2021. The Cambridge Greek Lexicon. J. Diggle, B.L. Fraser, P. James, O.B. Simkin, A.A. Thompson, S.J. Westripp (eds.). Vol. 2: $\mathrm{K}-\Omega$. Cambridge.

Domínguez A.J. 1989. La colonización griega en Sicilia. Griegos, indígenas y púnicos en la Sicilia Arcaica: Interacción y acculturación. Vols. 1-2. Oxford.

Domínguez A.J. 2006. Greeks in Sicily. In: G.R. Tsetskhladze (ed.), Greek Colonisation an Account of Greek Colonies and other Settlements Overseas. Vol. 1. Leiden; Boston, 253-357.

Dvoretsky I.Ch. 1958. Drevnegrechesko-russrij slovar' [Greek-Russian Dictionary]. Vol. 2. Moscow (in Russian).

Erler M. 2019. Platon und seine Rhetorik. In: M. Erler, Chr. Tornau (hrsg.), Handbuch Antike Rhetorik. Berlin; Boston, 315-338.

Flower M.A. 1994. Theopompus of Chios. History and Rhetoric in the Fourth Century BC. Oxford.

Fornara Ch.W. 1968. Hellanicus and an Alcmaeonid Tradition. Historia 17/3, 382-383.

Fornara Ch.W. 1983. The Nature of History in Ancient Greece and Rome. Berkeley, Los Angeles; London.
Fowler R.L. 1996. Herodotus and his contemporaries. JHS, 116, 62-87.

Fox M. 1993. History and Rhetoric in Dionysius of Halicarnassus. JRS 83, 31-47.

Fragoulaki M. 2020a. Introduction - Collective Memory in Ancient Greek Culture: Concepts, Media, and Sources. In: C. Constantakopoulou, M. Fragoulaki (eds.), Shaping Memory in Ancient Greece: Poetry, Historiography, and Epigraphy (Histos. Supplement 11). Newcastle Upon Tyne, IX-XL.

Fragoulaki M. 2020b. Thucydides Homericus and the Episode of Mycalessus (Thuc. 7.29-30): Myth and History, Space and Collective Memory. In: C. Constantakopoulou, M. Fragoulaki (eds.), Shaping Memory in Ancient Greece: Poetry, Historiography, and Epigraphy (Histos. Supplement 11). Newcastle Upon Tyne, 37-86.

Friedman D.A. 2020. [Rev.:] Richard L. Hunter, Casper C. de Jonge (eds.) Dionysius of Halicarnassus and Augustan Rome: Rhetoric, Criticism and Historiography (Greek Culture in the Roman World). Cambridge: Cambridge University Press, 2019. JRS 110, 289-291.

Fraser P.M. 1970. Aristophanes of Byzantion and Zoilus Homeromastix in Vitruvius. A note on Vitruvius VII, Praef. §§ 4-9. Eranos: Acta philologica suecana $68,115-122$.

Fromentin V. 2010. Philistos de Syracuse, imitateur de Thucydide? Réexamen du témoignage de Denys d'Halicarnasse. In: V. Fromentin, S. Gotteland, P. Payen (eds.), Ombres de Thucydide. La réception de l' historien depuis l'Antiquité jusqu'au début du XXe siècle. Actes des colloques de Bordeaux, les 16-17 mars 2007, de Bordeaux, les 30-31 mai 2008 et de Toulouse, les 23-25 octobre 2008. Bordeaux, 103-118.

Fromentin V., Gotteland S. 2015. Thucydides' Ancient Reputation. In: C. Lee, N. Morley (eds.), A Handbook to the Reception of Thucydides. Malden, MA; Oxford, 13-25.

Gabba E. 1991. Dionysius and the History of archaic Rome. Berkeley; Los Angeles; Oxford.

Galanin R.B. 2016. Ritorica Platona i Gorgija [The Rhetoric of Protagoras and Gorgias]. St. Petersburg (in Russian).

Galanin R.B. 2020. Ritoricheskoe izmerenie dialoga 'Lisid' [The Rhetorical Dimension of Plato's 'Lysis']. PlI 13, 92-112 (in Russian).

Gärtner H. 1964a. Hellanikos [1]. KP 2, 1004-1006.

Gärtner H. 1964b. Zoilos [4]. KP 5, 1549-1550.

Gärtner H. 1978. Zoilos (Homeromastix) [14]. RE. Supplement 15, 1531-1554. 
Gasparov M.L. 1997. Nepolnota i simmetrija v "Istorii" Gerodota [Incompleteness and symmetry in Herodotus' "History"]. In: Gasparov M.L. Izbrannye trudy [Selected works]. T. 1. Moscow, 483-489 (in Russian).

Gelzer Th. 1979. Klassizismus, Attizismus und Asianismus. In: H. Flashar (hrsg.), Le classicism à Rome aux Iers siècles avant et après J.$C$. Vandoeuvres-Genève, 1-55.

Gershon Y. 2021. [Rev.:] Friedrich Meins, Paradigmatische Geschichte: Wahrheit, Theorie und Methode in den 'Antiquitates Romanae' des Dionysios von Halikarnassos, Stuttgart: Franz Steiner Verlag, 2019. Anabases: Traditions et Réceptions de l'Antiquité [Online] 33, 289-290 (Online since 10 April 2021. URL: http://journals.openedition.org/anabases/12283).

Goold G.P. 1961. A Greek Professorial Circle at Rome. TPAPhA 92, 168-192.

Goulet-Cazé M.-O. 2018. Zoïlos d'Amphipolis [Z 32]. In: R. Goulet (ed.), Dictionnaire des philosophes antiques. T. VII: d'Ulpien à Zoticus avec des compléments pour les tomes antérieurs. Paris, 421-436.

Glukhov A.A. 2014. Perekhlest volny. Politicheskaja logika Platona i postnitseanskoe preodolenie platonizma [Wave overlap. Plato's political logic and the post-Nietzschean overcoming of Platonism]. Moscow (in Russian).

Grene D. 1967. Greek Political Theory: The Image of Man in Thucydides and Plato. Chicago.

Grethlein J. 2009. How Not to Do History: Xerxes in Herodotus' Histories Grethlein. AJPh 130/2, 195-218.

Griswold C.L. 1986. Self-knowledge in Plato's Phaedrus. New Haven.

Grube G.M.A. 1950. Dionysius of Halicarnassus on Thucydides. Phoenix 4, 95-110.

Grube G.M.A. 1965. The Greek and Roman Critics. London.

Hamel D. 2012. Reading Herodotus: A Guided Tour through the Wild Boars, Dancing Suitors, and Crazy Tyrants of The History. Baltimore; London.

Hanink J. 2021. Chimeras of Classicism in Dionysius of Halicarnassus' Reception of the Athenian Funeral Orations. In: M. Fantuzzi, H. Morales, T. Whitmarsh (eds.), Reception in the Greco-Roman World. Literary studies in Theory and Practice. Cambridge, 145-166.

Hartmann L. 2020. Die grosse Rede des Timaios ein Beispiel wahrer Rhetorik? In: Ch. Jorgenson, F. Karfík, Š Š Śpinka (eds.), Plato's Timaeus - Proceedings of the Tenth Symposium Platonicum Pragense. Leiden; Boston, 22-48.
Hau L.I. 2016. Moral History from Herodotus to Diodorus Siculus. Edinburgh.

Heath M. 1989. Dionysius of Halicarnassus "On Imitation". Hermes 117, 370-373.

Herington J. 1991. The Closure of Herodotus' Histories. ICS 16, 149-160.

Hidber Th. 1996. Das klassizistische Manifest des Dionys von Halikarnass. Die Praefatio zu De oratoribus veteribus: Einleitung, Übersetzung, Kommentar. Stuttgart; Leipzig.

Hornblower S. 1995. The fourth-century and Hellenistic Reception of Thucydides. JRS 115, 4768.

Hunter R.L. 2012. Plato and the Traditions of Ancient Literature: The Silent Stream. Cambridge.

Hunter R.L. 2019. Dionysius of Halicarnassus and the Idea of the Critic. In: R.L. Hunter, C.C. de Jonge (eds.), Dionysius of Halicarnassus and Augustan Rome: Rhetoric, Criticism and Historiography. Cambridge, 37-55.

Hunter R.L., de Jonge C.C. (eds.). 2019. Dionysius of Halicarnassus and Augustan Rome: Rhetoric, Criticism and Historiography. Cambridge.

Hunter V. 1977. The Composition of Thucydides' History. A New Answer to the Problem. Historia 26/3, 269-294.

Iglesias-Zoido J.C. 2012. Thucydides in the School Rhetoric of the Imperial Period. GRBS 52, 393420.

Irwin E. 2013. The hybris of Theseus' and the Date of the Histories. In: B. Dunsch, K. Ruffing, K. Droß-Krüpe (hrsg.), Herodots Quellen - Die Quellen Herodots. Wiesbaden, 7-84.

Irwin E. 2015. Dionysius of Halicarnassus' On Thucydides and Thucydides' rhetoric of the episodic. In: Ch. Werner, A. Dourado-Lopes, E. Werner (eds.), Tecendo narrativas: unidade e episódio na literatura grega antiga. São Paulo, 121-199.

Irwin E. 2018. The End of the Histories and the End of the Atheno-Peloponnesian Wars. In: T. Harrison, E. Irwin (eds.), Interpreting Herodotus. Oxford, 279-234.

Ivashkiv-Vashchuk O. 2020. Dionisij Galikarnas'kij: na mezhi kritiki i ritoriki [Dionysius of Halicarnassus: On the verge of criticism and rhetoric]. Naukovi zapiski Ukrains'kogo katolits'kogo universitetu. Serija "Filologija" [Bulletin of the Ukrainian Catholic University. Series "Philology"] 1. Lvov, 63-72 (in Ukrainian).

Jacoby F. 1912. Hellanikos (7) von Lesbos. RE 8/1, 104-153.

Jacoby F. 1949. Atthis. The Local Chronicles of Ancient Athens. Oxford. 
Jacoby F. 1956. Griechische Historiker. Stuttgart. Jónsson S.L. 2021. James among the Classicists: Reading the Letter of James in Light of Ancient Literary Criticism. Göttingen.

Joyce C. 1999. Was Hellanikos the First Chronicler of Athens? Histos 3, 1-17.

Kennedy S. 2018. How to write history: Thucydides and Herodotus in the ancient rhetorical tradition. A Dissertation Presented in Partial Fulfillment of the Requirements for the Degree Doctor of Philosophy in the Graduate School of the Ohio State University (URL: http://etd. ohiolink.rdu).

Kennedy S. 2018b. A Classic Dethroned: The Decline and Fall of Thucydides in Middle Byzantium. GRBS 58/4, 607-635.

Laird A. 2009. The Rhetoric of Roman Historiography. In: A. Feldherr (ed.), The Cambridge Companion to the Roman Historians. Cambridge, 197-213.

Lane Fox R. 1986. Theopompus of Chios and the Greek World, 411-322 BC. In: J. Boardman, C.E. Vaphopoulou-Richardson (eds.), Chios. A Conference at the Homereion in Chios 1984. Oxford, 105-120.

Laqueur R. 1934. Theopompos (9) aus Chios. RE $5 \mathrm{~A} / 2,2176-2223$.

Lateiner D. 1989. The Historical Method of Herodotus. Toronto.

Lenfant D. 2009. Les Histoires perses de Dinon et d'Héraclide. Fragments édités, traduits et commentés. Paris.

Lévy M. 2010. L'imitation de Thucydide dans les opuscules rhétoriques et les antiquités romaines de Denys d'Halicarnasse. In: V. Fromentin, S. Gotteland, P. Payen (eds.), Ombres de Thucydide. La Réception de l'historien, de l'Antiquité au XXe siècle. Actes des colloques de Bordeaux, les 16-17 mars 2007, de Bordeaux, les 30-31 mai 2008 et Toulouse, les 23-25 octobre 2008. Bordeaux, 51-61.

Lockwood J.F., Browning R. 2012. Zoïlus. $O C D^{4}$, 1591-1592 (=OCD $\left.{ }^{3}, 1639\right)$.

Losev A.F. 1977. Antichnaja filosofija istorii [Ancient Philosophy of History]. Moscow (in Russian).

Luschnat O. 1970. Thukydides. RE. Supplement 12, 1085-1354.

Mamardashvili M.K. 1997. Lektsii po antichnoj philosofii [Lectures on Ancient Philosophy]. Moscow (in Russian).

Mara G.M. 2008. The Civic Conversations of Thucydides and Plato. Classical Political Philosophy and the Limits of Democracy. Albany, NY.
Mara G.M. 2017. Political Philosophy in an Unstable World: Comparing Thucydides and Plato on the Possibilities of Politics. In: K.R. Balot, S. Forsdyke, E. Foster (eds.), The Oxford Handbook of Thucydides. Oxford, 531-547.

Marincola J. 2014. Rethinking Isocrates and Historiography. In: G. Parmeggiani (ed.), Between Thucydides and Polybius: The Golden Age of Greek Historiography. Washington, 39-61.

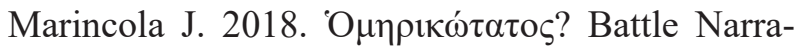
tives in Herodotus. In: E. Bowie (ed.), Herodotus - Narrator, Scientist, Historian. Berlin; Boston, 3-24.

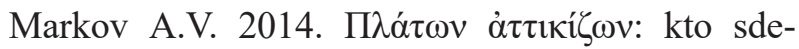
lal Platona klassikom atticheskogo narechija?

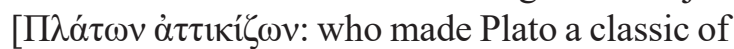
the Attic dialect?]. PlI 1, 173-184 (in Russian).

Matijašić I. 2018. Shaping the Canons of Ancient Greek Historiography: Imitation, Classicism, and Literary Criticism. Berlin; Boston.

Matijašić I. 2020. [Rev.:] Friedrich Meins, Paradigmatische Geschichte: Wahrheit, Theorie und Methode in den 'Antiquitates Romanae' des Dionysios von Halikarnassos, Stuttgart: Franz Steiner Verlag, 2019. BMCR 2020.07.14 (URL: https://bmcr.brynmawr.edu/2020/2020.07.14).

Matthaios S. 2002. Zoilos [1]. NP 12/2, 825.

Meins F. 2019. Paradigmatische Geschichte: Wahrheit, Theorie und Methode in den "Antiquitates Romanae" des Dionysios von Halikarnassos. Stuttgart.

Meritt B.D. 1962. The Seasons in Thucydides. Historia 11/4, 436-446.

Miano D. 2020. The explosion of Dionysius of Halicarnassus: Ghosts of Rhetoric from the $A r$ tes historicae to Posrmodernist Historiography. Histos 14, CLXXV-CLXXXVI.

Moles J. 1996. Herodotus Warns the Athenians. In: F. Cairns, M. Heath (eds.), Roman Poetry and Prose, Greek Poetry, Etymology, Historiography. Leeds, 259-284.

Möller 2007: Möller A. The Beginnings of Chronography: Hellanicus' Hiereiai. In: N. Luraghi (ed.), The Historian's Craft in the Age of Herodotus. Oxford, 241-262.

Moore Chr. 2013. Deception and Knowledge in the Phaedrus. Ancient Philosophy 33/1, 97-110.

Mosshammer A.A. 1973. The Apollodoran Akmai of Hellanicus and Herodotus. GRBS 14/1, 5-13.

Nicholson E. 2020. Dionysius between Greece and Rome. [Rev.:] Hunter (R.), De Jonge (C. C.) (edd.) Dionysius of Halicarnassus and Augustan Rome: Rhetoric, Criticism and Historiography. Cambridge: Cambridge University Press, 2019. $C R$ 70/1, 52-55. 
Niese B. 1888. Die Chroniken des Hellanikos. Hermes 23/1, 81-91.

Novokhatko A. 2020. Homeric Hermeneutics on the way from Athens to Alexandria. In: A. Rengakos, P. Finglass, B. Zimmermann (eds.), More than Homer Knew - Studies on Homer and His Ancient Commentators. Berlin; Boston, 87145.

Oakley S.P. 2019. The Expansive Scale of the Roman Antiquities. In: R.L. Hunter, C.C. de Jonge (eds.), Dionysius of Halicarnassus and Augustan Rome: Rhetoric, Criticism and Historiography. Cambridge, 127-160.

Osipova O.V. 2009. Drevnegrecheskie istoriki v ritoricheskikh traktatakh Dionisija Galikarnasskogo [The Greek historians in the rhetorical treatises of Dionysius of Halicarnassus]. IJaKF 13, 462-466 (in Russian).

Osipova O.V. 2010. Dionisij Galikarnasskij o rechakh v "Istorii" Fukidida [Dionysius of Halicarnassus on speeches in the "History" of Thucydides]. In: A.I. Solopov (ed.), Voprosy klassicheskoj filologii [A Questions of Classical Philology] 15: NYMФ $\Omega$ N ANTPON (Cave of Nymphs): Collection of articles in honor of A.A. Takho-Godi. Moscow, 323-329 (in Russian).

Osipova O.V. 2011a. Dionisij Galikarnasskij ob otstuplenijakh $\mathrm{v}$ istoricheskikh sochinenijakh [Dionysius of Halicarnassus on digressions in historical writings]. IJaKF 15, 433-437 (in Russian).

Osipova O.V. 2011b. "Nagljadnost" (enargeia) v "Istorii" Fukidida [Enargeia in the "History" of Thucydides]. Aristej 3, 109-114 (in Russian).

Osipova O.V. 2013. OIKONOMIA: Dionisij Galikarnasskij o kompozitsii istoricheskikh sochinenij [Dionysius of Halicarnassus on the structure of historical works]. AMA 16, 71-76 (in Russian).

Osipova O.V. 2015. Interpretatsija teksta literaturnogo proizvedenija v traktate Dionisija Galikarnasskogo "O Fukidide" [Interpretation of the Literary work in Dionysius of Halicarnassus' "On Thucydides"]. Problemy istorii, filologii, kul'tury [Journal of Historical, Philological and Cultural Studies] 3, 22-29 (in Russian).

Osipova O.V. 2018. "Teatral'nost"” v drevnegrecheskikh istoricheskikh sochinenijakh ["Theatricality" in Ancient Greek historiography]. IJaKF 22, 986-992 (in Russian).

Osipova O.V. 2019. Dionisij Galikarnasskij ob "istoricheskom" stile [Dionysius of Halicarnassus on the "historical" style]. IJaKF 23, 828-833 (in Russian).
Osipova O.V. 2021. Dionisij Galikarnasskij ob izlozhenii drevnejshej istorii [Dionysius of Halicarnassus on the presentation of the earliest history]. IJaKF 24/2, 996-1002 (in Russian).

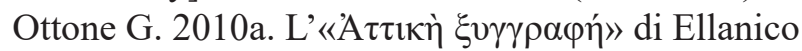
di Lesbo. Una Lokalgeschichte in prospettiva eccentric. In: C. Bearzot, F. Landucci (eds.), Storie di Atene, storia dei Greci. Studi e ricerche di attidografia. Milano, 53-111.

Ottone G. 2010b. Scrivere la storia dopo Tucidide: Teopompo di fronte all'Ateniese dalla prospettiva di Polibio e Dionigi di Alicarnasso. In: V. Fromentin, S. Gotteland, P. Payen (eds.), Ombres de Thucydide. La Réception de l'historien, de l'Antiquité au XXe siècle. Actes des colloques de Bordeaux, les 16-17 mars 2007, de Bordeaux, les 30-31 mai 2008 et Toulouse, les 23-25 octobre 2008. Bordeaux, 307-326.

Ottone G. 2017. La philaletheia come expertise etica dello storico politicamente impegnato. Il caso di Teopompo. Dialogues d'histoire ancienne. Supplément 17, 101-124.

Pape W. 1908. Handwörterbuch der griechischen Sprache: in 4 Bänden. Griechisch-Deutsches Handwörterbuch. Bd. 2: $\Lambda-\Omega$. 3. Aufl. 5. Abdr. Bearbeitet von M. Sengebusch. Braunschweig.

Parmeggiani G. 2014. Introduction. In: G. Parmeggiani (ed.), Between Thucydides and Polybius: The Golden Age of Greek Historiography. Washington, 1-6.

Parmeggiani G. 2016. Homeric Overtones and Comic Devices in Theopompus' Criticism of Philip's Companions. Ktèma: Civilisations de l'Orient, de la Grèce et de Rome antiques 41/1, 393-406.

Pavlova A.V. 2019. Arist. Poet. 1461b1-3: A broad hint at Zoilus? Philologia classica 14/1, 149154.

Pearson L. 1939. Early Ionian Historians. Oxford (repr.: Westport, 1975).

Pédech P. 1989. Trois historiens méconnus, Théopompe, Duris, Plytarque. Paris.

Pelling C.B.R. 2006. Homer and Herodotus. In: M.J. Clarke, B.G.F. Currie, R.O.A.M. Lyne (eds.), Epic Interactions: Perspectives on Homer, Virgil, and the Epic Tradition. Presented to Jasper Griffin by Former Pupils. Oxford, 75-104.

Pelling C.B.R. 2019. Herodotus and the Question Why. Austin.

Pelling C.B.R. 2020. Herodotus and the Question Why. In: C. Constantakopoulou, M. Fragoulaki (eds.), Shaping Memory in Ancient Greece: Poetry, Historiography, and Epigraphy (Histos. Supplement 11), 1-35. 
Perrin B. 1901. The Iepeiai of Hellanicus and the Burning of the Argive Heraeum. AJPh 22/1, $39-43$.

Poletti B. 2019. [Rev.:] Richard L. Hunter, Casper C. de Jonge (eds.) Dionysius of Halicarnassus and Augustan Rome: Rhetoric, Criticism and Historiography. Greek Culture in the Roman World. Cambridge: Cambridge University Press, 2019. BMCR 2019.12.14 (URL: https:// bmcr.brynmawr.edu/2019/2019.12.14).

Polychronis Th. 2018. Hellanicos de Lesbos: Histoire des Origines, origines de l'Histoire. Paris (URL: https://www.theses.fr.2018AIXM0075).

Powell J.E. 1960. A Lexicon to Herodotus. 2nd ed. Hildesheim.

Pritchett W.K. 1964. Thucydides V. 20. Historia 13/1, 21-36.

Prokopenko V.V. 2016. Platon, ironik? [Plato, the Ironist?]. PlI 4, 11-23 (in Russian).

Raaflaub K.A. 2016. Die große Herausforderung: Herodot, Thukydides und die Erfindung einer neuen Form von Geschichtsschreibung. Historische Zeitschrift 302, 593-622.

Radermacher L. 1951. Artium scriptores: Reste der voraristotelischen Rhetorik. Sitzungsberichte. Österreichischen Akademie der Wissenschaften. Philologisch-historische Klasse 227/3. Wien.

Rawlings III.H.R. 1981. The Structure of Thucydides' History. Princeton.

Regali M. 2020. Zoilus (1). In: F. Montanari, F. Montana, L. Pagani (eds.), Lexicon of Greek Grammarians of Antiquity. Brill Online (URL: https://referenceworks.brillonline.com/entries/ lexicon-of-greek-grammarians-of-antiquity/*Zoilus_1).

Reid R.S. 1996. Dionysius of Halicarnassus's Theory of Compositional Style and the Theory of Literate Consciousness. Rhetoric Review 15/1, 46-64.

Reid R.S. 1997. "Neither Oratory nor Dialogue": Dionysius of Halicarnassus and the Genre of Plato's “Apology”. Rhetoric Society Quarterly 27/4, 63-90.

Rengakos A. 2006. Thucydides' Narrative: The Epic and Herodotean Heritage. In: A. Rengakos, A. Tsakmakis (eds.), Brill's Companion to Thucydides. Leiden; Boston, 279-300.

Roberts W.R. 1900. The Literary Circle of Dionysius of Halicarnassus. CR 14/9, 439-442.

Roberts W.R. 1910. Dionysius of Halicarnassus on Literary Composition. Being the Greek text of the "De compositione verborum". W.R. Roberts (ed. with introduce., trans., notes, glossary, appendices). London.
Rosen K. 2009. Herodots Schlusskapitel: Ein kritischer Blick auf Athen. In: M. Rathmann (hrsg.), Studien zur antiken Geschichtsschreibung. Bonn, 1-12.

Rushkin I.P. 2016. "O drevnikh oratorakh" Dionisija Galikarnasskogo - to zhe, chto ego uterjannoe sochinenie "O politicheskoj filosofii"? ["De antiquis oratoribus" by Dionysius of Halicarnassus - Identical to his lost treatise "On political philosophy”?]. Scripta antiqua 5, 267-276 (in Russian).

Russell D. 2012. Dionysius (7). $O C D^{4}, 460-461$.

Sacks K.S. 1983. Historiography in the Rhetorical Works of Dionysius of Halicarnassus. Athenaeum 61, 65-87.

Samons L.J.II. 2010. Thucydides and Plato on Democracy. $C R$ 60/1, 32-34.

Sánchez Jiménez F. 2007. Helánico en su Historia Ática (FGrHist 323 a T 8): Aspectos de la 'Pentecontecia' de Helánico e influencia sobre el relato de Tucídides. Hormos 9, 443-455.

Sanders L.J. 1995. Theopompus and the Dionysian Empire. Echos du monde classique: Classical views 39, n.s. 14/3, 337-353.

Scanlon T.F. 2015. Greek Historiography. Chichester; Malden, MA; Oxford.

Schindel U. 2004. Der Historiker Philistos von Syrakus und die rhetorische Figurenlehre. In: M. Janka (hrsg.), ЕГКYKАION KHПION (Rundgärtchen). Zu Poesie, Historie und Fachliteratur der Antike. München; Leipzig, 163-169.

Schirren Th. 2019. Lysias Ethographos. In: M. Erler, Chr. Tornau (hrsg.), Handbuch Antike Rhetorik. Berlin; Boston, 185-214.

Schorn S. 2019. Rhetorik und Historiographie. In: M. Erler, Chr. Tornau (hrsg.), Handbuch Antike Rhetorik. Berlin; Boston, 627-654.

Schultze C. 2000. Authority, Originality and Competence in the Roman Archaeology of Dionysius of Halicarnassus. Histos 4, 6-49.

Schultze C. 2019. Ways of Killing Women: Dionysius on the Deaths of Horatia and Lucretia. In: R.L. Hunter, C.C. de Jonge (eds.), Dionysius of Halicarnassus and Augustan Rome: Rhetoric, Criticism and Historiography. Cambridge, 161-179.

Semikolennykh M.V. 2015. Uchenie Platona ob oratorskom iskusstve $\mathrm{v}$ izlozhenii Vissariona Nikejskogo [Plato's Teaching on Eloquence in Basilios Bessarion's Reconstruction]. PlI 2, 172-184 (in Russian).

Shcherbakov F.B. 2021. Poetika smekha u Platona: $\mathrm{k}$ voprosy o genezise filosofskoj ironii [The Poetics of Laughter in Plato: Tot he Problem of Genesis of the Philosophical Irony]. PlI 14, 32-51 (in Russian). 
Sheehan S. 2018. A Guide to Reading Herodotus Histories. London; New York.

Shrimpton G.S. 1991. Theopompus the Historian. Montreal; Qaebec.

Sinitsyn A.A. 2009. V avguste 424-go. Uskorennym marshem ot Istma do Makedonii (Istoriko-geograficheskij aspect frakijskogo pokhoda Brasida). Chast' 1 [In August 424. Accelerated march from Isthmus to Macedonia (Historical and geographical aspect of Brasidas' Thracian campaign). Part 1]. AMA 13, 36-69 (in Russian).

Sinitsyn A.A. 2013. Fukidid i Gerodot, povlijavshie drug na druga? (po povodu odnogo "interesnogo njuansa") [Thucydides and Herodotus - had they influenced each other? (as to an "interesting nuance")]. AMA 16, 39-55 (in Russian).

Sinitsyn A.A. 2017a. Kanaty i mosty Greko-persidskoj voiny [Ropes and Bridges of the Persian War]. In: O.L. Gabelko, E.V. Rung, A.A. Sinitsyn, E.V. Smykov ( eds.), Iranica: Iranskie imperii i greko-rimskij mir $v$ VI v. do n.e. - VI v. n.e. [Iranica: Iranian Empires and the Greco-Roman World from the Sixth Century $B C$ to the Sixth Century AD]. Kazan, 137-171 (in Russian).

Sinitsyn A.A. 2017b. Gerodot ob izgnanii varvarov iz Evropy i problema zavershennosti pervoi 'Istorii' [Herodotus on the Banishment of the Barbarians out of Europe and the Issue of the Completeness of the First 'History']. Metamorfozy istorii [Metamorphoses of History] 10, 3592 (in Russian).

Sinitsyn A.A. 2019. $\tau \grave{\alpha}$ ő $\pi \lambda \alpha \tau \tilde{\omega} v \gamma \varepsilon \varphi v \rho \varepsilon ́ \omega v$ of the Persian War: Herodotus on the Banishment of the Barbarians out of Europe and the issue of the Completeness of the First the History. $A A L$ 65, 83-124.

Sinitsyn A.A., Surikov I.E. 2019. Novyj kollektivnyj trud ob "ottse istorii" kak uchenom i rasskazchike [A new collective work on the "father of history" as a scholar and narrator]. Mnemon 19/1, 183-216 (in Russian).

Sinitsyn A.A., Surikov I.E. 2020a. A New Collective Work on Herodotus as a Scientist and Narrator. Anabasis: Studia Classica et Orientalia 10, 357-383.

Sinitsyn A.A., Surikov I.E. 2020b. A chaotic tours of the "halls" of the Logoi of the Herodotus "Muses": Review of the English historiography on the "father of history" and his work in the new guidebook. $A A L 66,151-167$.

Sinitsyn A.A., Surikov I.E. 2021. [Rev.] S. Sheehan. A Guide to Reading Herodotus' Histories. London-New York: Bloomsbury Academic, 2018. VDI 81/2, 520-528 (in Russian).
Sobolevsky S.I. 1955. Fukidid [Thucydides]. In: S.I. Sobolevsky, M.E. Grabar'-Passek, F.A. Petrovsky (eds.), Istorija grecheskoj literatury [The History of Greek Literature]. Vol. 2. Moscow, 69-100 (in Russian).

Sobolevsky S.I. 1960. Dionisij Galikarnasskij [Dionysius of Halicarnassus]. In: S.I. Sobolevsky, M.E. Grabar'-Passek, F.A. Petrovsky (eds.), Istorija grecheskoj literatury [The History of Greek Literature]. Vol. 3. Moscow, 156-167 (in Russian).

Sonnabend H. 2004. Thukydides. Hildesheim; Zürich; New York.

Stal I.V. 1975. Logicheskij predel sofisticheskogo metoda literaturnoj kritiki (Zoil iz Amfipolja) [The logical limit of the sophistic method of literary criticism (Zoilos of Amphipolis)]. In: L.A. Freiberg (ed.), Drevnegrecheskaja literaturnaja kritika [Ancient Greek literary critics]. Moscow, 335-360 (in Russian).

Strogetsky V.M. 2009. Dionisij Galikarnasskij kak literaturnyj kritik i istorik [Dionysius of Halicarnassus as a literary critic and historian]. Iz istorii antichnogo obshchestva [From the History of Ancient Society]. 12. 130-138 (in Russian).

Strogetsky V.M. 2010. Stanovlenie istoricheskoj mysli v Drevnej Gretsii i vozniknovenie klassicheskoj grecheskoj istoriografii: Gerodot, Fukidid, Ksenofont. T. 1: Gerodot [The formation of historical thought in Ancient Greece and the emergence of Classical Greek historiography: Herodotus, Thucydides, Xenophon. Vol. 1: Herodotus]. Nizhny Novgorod (in Russian).

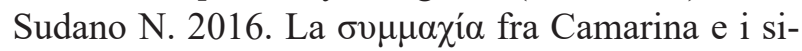
culi (Filisto, FGrHist 556 F5). Sicilia Antiqua: An International Journal of Archaeology 13, 193-200.

Surikov I.E. 2021. Gellanik i Afiny [Hellanicus and Athens]. Problemy istorii, filologii, kul'tury [Journal of Historical, Philological and Cultural Studies] 3, 176-196 (in Russian).

Svetlov R.V. 2016. Platon i Fukidid [Plato and Thucydides]. Vestnik of Saint Petersburg University. Serija 17 2, 34-41 (in Russian).

Szlezák T.A. 2012. Homer, oder Die Geburt der abendländischen Dichtung. München.

Szlezák T.A. 2015. O znachenii kljuchevykh ponjatij platonovskoj kritiki pis'ma: filologicheskij podkhod k 'Fedru' 274b-278e [On the Meaning of the Key Concepts in Plato's Criticism of Writing: A Philological Approach to 'Phaedrus' 274b-278e]. PlI 3, 65-91 (in Russian).

Tober D. 2017. Greek Local Historiography and its Audiences. CQ 67/2, 460-484. 
Toye D.L. 1995. Dionysius of Halicarnassus on the First Greek Historians. AJPh 116/2, 279-302.

Tufano S. 2019. Boiotia from Within. The Beginnings of Boiotian Historiography. Münster.

Vattuone R. 2014. Looking for the Invisible: Theopompus and the Roots of Historiography. In: G. Parmeggiani (ed.), Between Thucydides and Polybius: The Golden Age of Greek Historiography. Washington, 7-37.

Viidebaum L. 2019. Dionysius and Lysias' Charm. In: R.L. Hunter, C.C. de Jonge (eds.), Dionysius of Halicarnassus and Augustan Rome: Rhetoric, Criticism and Historiography. Cambridge, 106-124.

Viidebaum L. 2021. Creating the Ancient Rhetorical Tradition. Cambridge.

Walker J. 2005. Dionysius of Halicarnassus. In: M. Ballif, M.G. Moran (eds.), Classical Rhetorics and Rhetoricians: Critical Studies and Sources. Westport, 137-141.

Weaire G. 2002. The Relationship between Dionysius of Halicarnassus' "De Imitatione" and "Epistula ad Pompeium". CPh 97/4, 351-359.

Weaire G. 2005. Dionysius of Halicarnassus' Professional Situation and the "De Thucydide". Phoenix 59/3-4, 246-266.

Welser C. 2009. Two Didactic Strategies at the End of Herodotus' Histories (9.108-122). ClAnt 28/2, 359-385.

Werner D. 2010. Rhetoric and philosophy in Plato's Phaedrus. GR 57/1, 21-46.

Wiater N. 2011. The Ideology of Classicism: Language, History, and Identity in Dionysius of Halicarnassus. Berlin; New York.
Wiater N. 2018. Getting Over Athens: Re-Writing Hellenicity in the Early Roman History of Dionysius of Halicarnassus. In: M. Canevaro, B. Gray (eds.), The Hellenistic Reception of Classical Athenian Democracy and Political Thought. Oxford, 209-235.

Wiater N. 2019. Experiencing the Past: Language, Time and Historical Consciousness in Dionysian Criticism. In: R.L. Hunter, C.C. de Jonge (eds.), Dionysius of Halicarnassus and Augustan Rome: Rhetoric, Criticism and Historiography. Cambridge, 56-82.

Wille G. 1968. Zu Stil und Metode des Thukydides. In: H. Herter (hrsg.), Thukydides. Darmstadt, 683-716

Williams M.F. 2013. Zoilos of Amphipolis (71). In: I. Worthington (ed.), Brill's New Jacoby. BrillOnline (URL: https://referenceworks. brillonline.com/entries/brill-s-new-jacoby/zoilos-of-amphipolis-71-a71).

Yunis H. 2019. Dionysius' Demosthenes and Augustan Atticism. In: R.L. Hunter, C.C. de Jonge (eds.), Dionysius of Halicarnassus and Augustan Rome: Rhetoric, Criticism and Historiography. Cambridge, 83-105.

\section{Aleksandr A. Sinitsyn ORCID 0000-0001-9229-0217 The Russian Christian Academy for the Humanities, Saint Petersburg, Russia aa.sinizin@mail.ru}

Ph.D., CSc in History, Associate Professor, 